\title{
Silence is not Golden: Corporate Governance Standards, Transparency, and Performance*
}

\author{
Sridhar Arcot and Valentina Bruno ${ }^{\dagger}$ \\ Current version: April 2011
}

JEL Classification: G34, G38, K22, M40

\footnotetext{
${ }^{*}$ This paper is a revised version of one chapter of our PhD dissertations at the London School of Economics and previously circulated under the title "One size does not fit all, after all: Evidence from corporate governance". We are extremely grateful to the late Antoine Faure-Grimaud (our supervisor) for his advice and encouragement. We also thank our PhD examiners Hyun Song Shin and Denis Gromb for their comments and suggestions, and David Webb for the support provided. We also appreciate comments from Ron Anderson, Lucian Bebchuk, Jan Bena, Stijn Claessens, Andrew Ellul, Phil English, Mara Faccio, Jose-Miguel Gaspar, Yaniv Grinstein, Sudip Gupta, Robert Hauswald, Henry Hu, Luc Laeven, Colin Mayer, Christopher Polk, N.R. Prabhala, Michel Robe, Michela Verardo, and participants at various seminars and conferences (World Bank, Bank of England, London School of Economics, SEC, American University, ESSEC, Universita' Cattolica, Bocconi University, 4th International Conference on Corporate Governance in Birmingham, CAF Summer Research Conference at ISB, 1st Annual Conference on Empirical Legal Studies at Austin). We thank Dragana Cvijanovic, Terence Teo and Zhigang Qiu for excellent research assistance. Sridhar Arcot acknowledges support from the FMG and LSE. Valentina Bruno acknowledges financial support from Ente Luigi Einaudi. All errors are of course our own.

${ }^{\dagger}$ Sridhar Arcot: ESSEC Business School, Department of Finance, 95021 Cergy Pontoise Cedex, France, Tel: +33 (0) 1344330 77, Email: arcot@essec.fr. Valentina Bruno: American University, Kogod School of Business, Department of Finance and Real Estate, Washington DC, USA, Tel: 202466 2032, Email: bruno@american.edu
} 


\title{
Silence in not Golden: Corporate Governance Standards, Transparency, and Performance
}

\begin{abstract}
We examine corporate governance and disclosure choices in a regulatory environment suited to address the nature of governance as chosen by individual firms. In this environment, companies choose whether to comply with governance standards or to report and explain their non-compliance. By using a voluntary regulatory arena, we can observe the impact of different corporate characteristics on corporate governance choices. We find that firm ownership structure and firm growth opportunities affect the decision to deviate from regulatory standards. The disclosed reasons for deviation are often obscure and uninformative. Only those companies which adhere to the recommended standards or those with the highest level of disclosure have better performance. Our findings suggest that some companies adopt different corporate governance practices not because of their different characteristics but to extract private benefits.
\end{abstract}




\section{Introduction}

In this paper, we examine the corporate governance and disclosure choices of companies in an environment where they are not mandated to adopt prescribed governance practices and their effect on performance. The theoretical and economic rationale underpinning a non-mandatory corporate governance approach lies in the fact that there exists little or no reason to hypothesize that one governance structure is optimal for all firms. A single corporate governance standard may not increase net welfare for all firms that are forced to comply because companies have heterogenous characteristics that may warrant different governance structures. In fact, companies have different monitoring and advising needs related to their characteristics and their operating environment (Raheja, 2005; Adams and Ferreira, 2007). For instance companies with large shareholders have the incentive to collect information and the power to monitor managers, thus substituting the monitoring role of the board, alleviating free-rider problems (Shleifer and Vishny, 1986; Bolton and Von Thadden, 1998) and acting as an alternative governance mechanism (Aghion and Tirole, 1997). ${ }^{1}$

A non-mandatory system, however, can be a double-edged sword because managers might deviate from governance standards to hide their shirking and private benefit consumption in turn leading to higher agency costs (Shleifer and Vishny, 1997). If companies endogenously choose their governance structure to maximize profitability, we should not observe any difference in performance (Hermalin and Weisbach, 2003). By contrast, if managers or shareholders adopt corporate governance practices different from the standards for reasons other than profit maximization, they should be less profitable. To differentiate between governance choices driven by specific company characteristics for profit maximization (one-size-does-not-fit-all hypothesis) and self-serving goals (expropriation hypothesis), we estimate performance-governance regressions.

The data for our analysis comes from the annual reports of UK companies. We chose the UK as

\footnotetext{
${ }^{1}$ Because large shareholders have the incentive to collect information and the power to monitor the manager, the large shareholders substitute for the monitoring role of the board, choose their preferred project and formal authority prevails. In contrast, shareholders who are not informed lose control and the manager has real authority (effective control) (Aghion and Tirole, 1997).
} 
the setting of our study because the UK pioneered a corporate governance approach characterized by voluntary compliance with governance standards coupled with mandatory disclosure. In such a setting, companies can deviate from governance standards listed in a "Code of Best Practice" by explaining the reasons for deviating as part of compliance with the Listing Requirements (the "Comply or Explain" approach). This framework is ideal for studying corporate governance because it provides companies with an additional degree of freedom. For instance, the 2002 Sarbanes-Oxley Law and the NYSE listing standards in the US require that a majority of the board of directors must be independent and that board committees (audit, monitoring, and compensation) must be comprised entirely of independent directors. By contrast, UK firms do not have to conform to such requirements, provided they explain their reasons for not doing so. Based on the information contained in the corporate governance section of UK annual reports, we construct a unique dataset by hand-collecting details of both compliance with the UK corporate governance Code and explanations given for non compliance by FTSE350 non-financial companies between 1998 and 2004 .

Our analysis of firm corporate governance structures indicates that firm ownership structure and firm growth opportunities affect the decision to comply with corporate governance provisions. In particular, we find that family firms are less likely to comply with provisions related to the monitoring role of the board (e.g., the existence of independent non-executive directors), whereas firms with growth opportunities are less likely to have independent board committees (audit, compensation, or nomination committees). These results are consistent with the existing literature highlighting different monitoring and governance needs related to operational and ownership characteristics. We also find that family firms are less informative and in some cases even omit disclosures about their governance choices. Such companies do not communicate publicly to their shareholders the reasons why commonly considered good practices in corporate governance are not optimal for them. Thus, the large shareholders behave more like insiders and disclose as little as possible to other investors.

Our results from the performance-governance regressions show that companies that do not comply with corporate governance standards and do not explain the reasons have the lowest profitability, whereas companies that comply and those that do not comply but give informative explanations 
perform better than other companies. These findings suggest that the positive association between heterogeneous governance structures and performance is limited to those firms with the highest levels of governance standards or disclosure whereas silence and incomplete disclosure are associated with poor performance. Our results also suggest that compliance with governance standards and better disclosure of noncompliances are substitute governance and monitoring mechanisms that reduce agency costs.

This evidence is robust to various specifications, including different ways of measuring governance, use of individual governance provisions, use of an alternative indicator of the quality of disclosure practices (the S\&P Transparency Rankings), an alternative dependent variable (stock market returns), the inclusion of various control variables, and the use of an instrumental variables approach. Similar to Gompers, Ishii, and Metrick (2003) and Biddle, Hilary, and Verdi (2009), we also find a positive relationship between noncompliant governance practices, poor disclosure, and capital expenditures, which may explain what causes lower profitability. The evidence on capital expenditures supports the evidence on performance in that compliance with corporate governance standards and better disclosure alleviate agency problems and do not exacerbate moral hazard behavior.

The main contribution of the paper is in the combined analysis of corporate governance practices and disclosures in a non-mandatory setting where companies can choose different governance structures. By accounting for both the level of compliance and the quality ${ }^{2}$ of disclosure as two substitute governance mechanisms, our approach departs from a one-size-fits-all approach to corporate governance because it does not attribute worse governance to companies departing from governance standards and being transparent about their reasons. This allows us to fine-tune the identification strategy for well-governed companies and to detect whether companies deviate from governance standards because of different monitoring needs or for expropriation purposes. In particular, our findings suggest that companies that deviate from governance practices and are less transparent about their governance choices do not adopt different governance practices because of their different

\footnotetext{
2 "Quality" here is related to the concept of "transparency", defined as the ability of shareholders to comprehend the corporate governance decisions of the company.
} 
characteristics but they exploit the flexibility of the governance system to extract private benefits.

This study bridges two strands of the literature. First, recent empirical literature on boards highlights the structural differences across companies affecting board characteristics (Boone, Field, Karpoff, and Raheja, 2007; Harris and Raviv, 2008; Coles, Daniel, and Naveen, 2008, Linck, Netter, and Yang, 2008). This literature is related to theoretical arguments about the costs and benefits of insider monitoring (Raheja, 2005; Adams and Ferreira, 2007; Adams, Hermalin, and Weisbach, 2010) and the presence of large shareholders (Shleifer and Vishny, 1986; Aghion and Tirole, 1997; Bolton and Von Thadden, 1998). Despite recognizing that companies have heterogeneous characteristics that may justify different governance structures, the corporate governance literature for the most part has evaluated companies' corporate governance against a single governance standard and treated deviations from it as a sign of bad governance.

Second, the literature on disclosure has focused on the quality and discretion in corporate governance disclosure to understand investor protection (see, e.g., Leuz and Wysocki, 2008, for a review). This literature has also highlighted the association between differing disclosure choices and companies' characteristics. For instance, recent studies show that lower disclosure by concentrated family ownership is explained by the fact that large family holders behave more like insiders and have less incentives to disclose information (Ajinkya, Bhojraj, and Sengupta, 2005; Anderson, Duru, and Reeb, 2009; Chen, Chen, and Cheng, 2008). However, lower transparency can potentially hide self-interested managerial decisions that may not be in the shareholders' best interest (Shleifer and Vishny, 1986; Leuz, Nanda, and Wysocki, 2003; Lang, Lins, and Miller, 2004; Anderson, Duru, and Reeb, 2009) and managers tend to withhold information if it is bad news (Kothari, Shu, Wysocki, 2009). In this manner, low transparency weaken shareholders' ability to discipline managers. Consequently, less governance transparency can be related to an inefficient allocation of resources and worse firm performance (Shleifer and Vishny, 1997; Bushman and Smith, 2003; Klapper and Love, 2004; Durnev and Kim, 2006; Hope and Thomas, 2008).

Our results bring together and extend these strands of the literature and show that non compliance with some corporate governance practices is not necessarily a sign of bad governance. One- 
size-does-not-fit-all provided that companies are transparent about their governance choices and explain why a particular governance provision is not optimal for them. This evidence highlights that compliance with corporate governance standards ("Comply") and better disclosure ("or Explain") are in fact two substitute governance mechanisms. Our paper also complements and extends the literature on corporate governance codes of best practice (see, e.g., Conyon and Peck (1998), Dedman (2003), Dahya, McConnell and Travlos (2002), Dahya and McConnell (2007)). These studies mainly focus on compliance with governance standards, whereas we also take into account the reasons for a company's departure from the standards. Finally, our findings hold important policy implications in light of the widespread adoption of corporate governance Codes modeled on the UK system. Corporate governance regimes designed on the "Comply or Explain" system afford companies discretion in their choices; consequently, this system may be less efficient in countries where companies are less inclined to be transparent and are more likely to take advantage of the allowed flexibility for expropriation purposes.

The structure of the paper is as follows. Section 2 describes the sample selection and the corporate governance indicators. Sections 3 and 4 show the multivariate regressions, results and robustness tests. Section 5 summarizes and concludes.

\section{Sample and Data}

\subsection{The Combined Code Provisions}

We downloaded annual reports of companies belonging to the FTSE 350 index for the period 1998 - 2004 from Mergent Online. We chose this period because the Combined Code was in force continuously and with no amendments, after which it was subsequently updated by the Higgs Committee recommendations. Each annual report contains a corporate governance section that states the level of compliance with the Combined Code and an explanation in the case of noncompliance with any of its recommendations. Since the Combined Code was in effect from 31st December 1998 to 30th June 2004, we exclude annual reports of companies with financial year endings before and 
after those dates, respectively. As is common in the literature, we exclude 106 financial companies (SIC codes 60 - 69) (banks, insurance, REITs, equity investment trusts, etc.) because the regulatory environment for those companies differs significantly from that of non financial companies. Sometimes, the annual reports are missing in Mergent Online. We are therefore left with 1275 total company-year annual reports.

From each annual report we collect the statement of compliance and the exact explanation given in case of non compliance with the following eight provisions listed in the Combined Code $^{3}$ :

1. Separation of Chairman and CEO: There should be a clear division of responsibilities at the head of the company (Provision A.2.1);

2. Senior Non-executive Director (SNED): Whether the posts (Chairman/CEO) are held by different people or by the same person, there should be a strong and independent non-executive element on the board (SNED), with a recognized senior member other than the chairman to whom concerns can be conveyed (Provision A.2.1);

3. Non-executive Directors: They should comprise not less than one third of the board (Provision A.3.1);

4. Independent Non-Executive Directors: The majority of non-executive directors should be independent of management and free from any business or other relationship (Provision A.3.1);

5. The term of Service Contracts: it should be one year or less (Provision B.1.7);

6. Nomination Committee: it should be established to make recommendations to the board on all new board appointments. A majority of the members of this committee should be non-executive directors (Provision A.5.1);

\footnotetext{
${ }^{3}$ The Combined Code consists of eleven provisions, of which we analyze eight. We did not include in our analysis the provisions related to the directors' re-election, pay linked to performance, and the quality of the internal control systems, because all companies in the sample complied or stated their intention to comply with these provisions. The inclusion of these provisions would not have affected our results. Furthermore, judging the effective level of compliance of the provisions pertaining to pay-linked to performance and internal controls would have required additional information which was not available to us.
} 
7. Compensation Committee: it should be established for a transparent policy on executive compensation. It should consist exclusively of independent non-executive directors (Provisions B.1 and B.2.2);

8. Audit Committee: it should be established for transparent arrangements on the financial reporting. The committee should consist of at least three non-executive directors, a majority of whom should be independent (Provision D.3).

\subsection{The explanations for the Combined Code non-compliances}

Because companies are allowed to depart from corporate governance practices if they have valid reasons, the assessment of the level of compliance with certain provisions does not alone measure the quality of an individual company's corporate governance. The "Comply or Explain" approach requires companies to explain the reasons of their corporate governance deviations and it must be for shareholders to evaluate this part of the company's statement. ${ }^{4}$ The Financial Reporting Council (FRC), the UK regulator responsible for promoting confidence in corporate governance and reporting, has stated that "to be fully effective the "Comply or Explain" requires companies to provide their shareholders with the information they need to judge the adequacy of the company's governance arrangements, and it requires investors to consider those arrangements on their merits, even where they deviate from the Code".$^{5}$ The quality and level of disclosure provided by companies when deviating from corporate governance standards is thus a component of the governance quality of a company, especially in light of the specific role shareholders are assigned in the monitoring of the explanations.

If a company does not comply with some corporate governance provisions and does not provide a valid justification, shareholders have to assume that it cannot or does not want to provide the reasons for deviating, especially if the reasons are associated with self-maximizing purposes. In

\footnotetext{
${ }^{4}$ All companies incorporated in the UK and listed on the Main Market of the London Stock Exchange are required under the Listing Rules to report on how they have applied the Combined Code in their annual report. However, the Code does not propose any explicit penalty for not providing explanations.

${ }^{5} 2009$ Review of the Effectiveness of the Combined Code, page 25.
} 
fact, poor disclosure is generally an indicator of bad governance. For instance, Leuz, Nanda, and Wysocki (2003) argue that managers and controlling owners manage the level and variability of reported earnings in order to mask true firm performance and to conceal their private control benefits from outsiders. Lang, Lins, and Miller (2004) find that firms with governance problems are likely to be less forthcoming in terms of disclosure, giving analysts less information to work with in assessing investment potential. Anderson, Duru, and Reeb (2009) show that disclosure quality appears to be the primary extraction channel in family owned companies where the owners adversely affect disclosure quality to extract firm resources. Kothari, Shu, and Wysocki (2009) show that managers tend to withhold information if it is bad news and Hollander, Pronk, and Roelofsen (2010) show that investors interpret lack of disclosure negatively.

When analyzing the companies' annual reports we first find several instances of non compliance statements where there is no explanation of the reason why a company decided to opt out from certain governance standards. Such companies not only do not follow corporate governance standards, but they also do not provide any justification to their shareholders of why the adoption of a corporate governance provision is not optimal to them. The absence of any explanation is an objective fact and it can be easily detected in the corporate governance section of the annual report.

We then classify the explanations provided by noncompliant companies based on their level of informativeness and verifiability. The analysis of the explanations to assess the reasons for not complying with general standards requires qualitative judgment on our part and necessarily contains some subjectivity, which we try to minimize by using objective and measurable criteria. As discussed in the robustness checks, we also had three research assistants who independently classified the companies' explanations.

The Combined Code does not prescribe a format that companies have to follow when giving such explanations, but states that the explanation has to be narrative and refer to the company's unique circumstances. In this sense, the Combined Code approach is characterized by mandatory disclosure, but with discretion over its form and content. ${ }^{6}$ We find different degrees of "narration"

\footnotetext{
${ }^{6}$ "In the first part of the statement, the company will be required to report on how it applies the principles in
} 
and "specific circumstances" in the explanations given in the annual reports. In particular, some explanations are more informative and provide more details than others, whereas some companies give the same boilerplate explanations, like the following explanation found in Reuters 1999 Annual Report: "The Board has not identified a senior independent non-executive director, as specified by the Code, because it considers such an appointment to be unnecessary at present". Reuters justifies the non appointment of a senior figure in the board as unnecessary at the present, without further details. This explanation clearly fails to identify specific circumstances for departing from best practice, and the same words ("because it considers it to be unnecessary at present") are also used by other non compliant companies. Therefore, such explanation is neither narrative nor unique to the company.

Consider, on the contrary, the following explanation in GlaxoSmithKline 2002 Annual Report: "In determining its overall policy in respect of service contracts, the Committee aims to balance the costs associated with any early termination provisions with the need to protect GlaxoSmithKline's intellectual property rights. [...] Executive Directors are employed on service contracts under which the employing company is required to give 24 calendar months' notice of termination. [...] Executive Directors' service contracts contain 'garden leave', non-competition, non-solicitation and confidentiality clauses. [...] The Remuneration Committee currently believes that one year contracts would not be in the best interest of GlaxoSmithKline with regard to offering a globally competitive overall remuneration package and securing maximum protection for its intellectual property rights". The contents of this explanation are narrative (information on the context and the motivations are provided) and contain verifiable and specific elements (the company belongs to a competitive industry and it aims at protecting its property rights by offering two years contracts containing "garden leave", non competing and confidentiality clauses), which are unique to the company's

the Combined Code. We make clear in our report that we do not prescribe the form or content of this part of the statement, the intention being that companies should have a free hand to explain their governance policies in the light of the principles, including any special circumstances applying to them which have led to a particular approach. It must be for shareholders and others to evaluate this part of the company's statement. [...] In our report we make clear that companies should be ready to explain their governance policies, including any circumstances justifying departure from best practice; and that those concerned with the evaluation of governance should do so with common sense, and with due regard to companies' individual circumstances." (Points 4 and 6 of the Preamble to the Combined Code) 
circumstances. For these specific reasons, GlaxoSmithKline believes that one year contracts would not be in the company's best interest. This explanation is also unique to GlaxoSmithKline and no other company provides the same one. ${ }^{7}$

Based on the presence of verifiable and specific elements related to the company's circumstances, we classify the explanations on a Type 0 to 5 scale, from the least (absence of any explanation) to the most (unique and specific) informative. Following our taxonomy, "Type 5" are genuine, detailed explanations unique to the company (as in GlaxoSmithKline); "Type 4" describe temporary verifiable situations due to which the company is not compliant (e.g., a board member resignation), but no further information is provided on the company's circumstances; "Type 3" and "Type 2" explanations vaguely provide some explanations which are not specific to company's circumstances or simply too general, respectively; "Type 1" explanation is totally uninformative and uses some standard sentences provided by various companies, such as asserting that compliance is "unnecessary", without further explanations (as in Reuters). Finally, "Type 0" occurs when there is a non compliance statement in the annual report, but no explanation is provided. The omission of any type of explanation is a purely objective fact and does not suffer of any subjective judgment in its classification.

The following caveat applies to our classification. We are unable to judge the veracity of the explanation from a business perspective, but we nevertheless verify that the events and circumstances described in the explanation correspond to reality. Our perspective is that of an individual uninformed shareholder who evaluates the corporate governance statement contained in the annual report and judges its degree of informativeness. In this sense, the analysis of the quality of explanations is related to the concept of transparency, defined as the ability of shareholders to comprehend the corporate governance decisions of the company. On the other hand, if companies could easily write false or narrative explanations for non compliance we would not observe boilerplate explanations or, more worrying, lack of any explanation. ${ }^{8}$

\footnotetext{
${ }^{7}$ For additional examples and discussion, see also Arcot and Bruno (2007).

${ }^{8}$ The lack of any explanation and a common use of boilerplate explanations has been also recognized by the Financial Reporting Council (FRC) in its 2009 Review of the Effectiveness of the Combined Code. Particular concerns
} 


\subsection{Corporate Governance Indicators}

\subsubsection{Corporate governance compliance indicators}

We construct an indicator that measures divergence from any Combined Code practice. Specifically, we look at a company's overall level of compliance with all the provisions of the Code and we construct the following dummy variable:

- Dummy $C G$ Deviation that takes the value 0 if a company is fully compliant with all the Combined Code provisions, and 1 otherwise.

We also construct an indicator that measures the distance from the governance standards, similarly to the Gompers et al. (2003) methodology:

- \# CG Deviations that counts the total number of non-compliances, and it may range between 0 and 8 .

\subsubsection{Corporate governance and disclosure indicators}

Based on the analysis of the explanations, we create an indicator capturing the absence of an explanation for any non compliant provision:

- Dummy No Disclosure equal to 1 if no explanation is provided, and 0 otherwise. Such an indicator identifies those companies that do not comply and do not disclose any information to shareholders about their governance decision. The omission of any type of explanation does not suffer of any subjective judgment in its classification.

We then construct a corporate governance index reflecting both the level of compliance with the Combined Code principles and the quality of explanations in the case of noncompliance. Indicators, like Dummy CG Deviation or \# CG Deviations, which identify better governed companies by only

were raised about the amount of information provided by non compliant companies. Some companies suggested that it may be useful for the FSA and/or the FRC to undertake a formal monitoring of the "Comply or Explain" element of the corporate governance statement to ensure that companies were meeting the requirement in the Listing and Disclosure and Transparency Rules. 
analyzing adherence to governance provision(s) would discard relevant information and impose a one-size-fits-all framework on what is expected from companies. This aspect is further complicated by the existence of heterogeneous corporate structures (Boone, Field, Karpoff and Raheja; 2007; Coles, Daniel and Naveen, 2008), and disclosure incentives (Healy and Palepu, 2001; Core, 2001; Ball, Robin, and Wu, 2003; Leuz and Wysocki, 2008).

We thus need a quantitative measure of corporate governance that does not penalize companies departing from best practice for valid reasons. Our governance measure will be lower when the deviation from governance standards is not fully explained because lack of transparency is a sign of bad governance (Leuz, Nanda, and Wysocki, 2003; Lang, Lins, and Miller, 2004; Anderson, Duru, and Reeb, 2009). We call this measure $C G \&$ $\mathcal{G}$ Disclosure Index because it reflects both adherence to the corporate governance standards and the level of disclosure of relevant information related to the company's circumstances. We construct the index as follows.

Compliance with all provisions alleviates the principal-agent problem because it gives monitoring control to the board of directors and provides a greater balance of power, thus reducing the likelihood of entrenchment. Adherence to commonly recognized standards of good corporate governance is also verifiable and fully transparent and we give 5 points to each corporate governance provision a company complies with. We also give 5 points in cases of non-compliances which are explained in detail because there should be no difference between a compliant company and a noncompliant company that deviates from standards for good and valid reasons that are fully disclosed because better transparency is less likely associated with agency issues. A company departing from best practice for valid reasons is therefore not penalized in the classification of its governance quality. We then progressively attribute a lower score to explanations which are less informative, not verifiable or not unique to the company's circumstances because lack of transparency can be associated with self-serving purposes. Based on the classification of the quality of explanations, we give 4 points to transitional non-compliance situations, 3 or 2 points when the explanation is vague and not verifiable, 1 point when it is uninformative, and 0 points when no explanation is given. 
- Formally, we compute the $C G \& \mathcal{E}$ Disclosure Index as follows:

$$
\begin{aligned}
& C G \mathscr{G} \text { Disclosure Index }= \\
& (5 * \text { Number of compliances })+\sum(\text { Explanation Type } * \text { Number of non-compliances })
\end{aligned}
$$

For instance, the $C G \mathscr{E}$ Disclosure Index of a company fully compliant with all eight provisions is $5 * 8=40$, the same of a non-compliant company giving all informative explanations (Type 5) for its non-compliances. A company with one non-compliance for which no explanation is provided (classified as Type 0) has a $C G \mathscr{E}$ Disclosure Index of $(5 * 7)+(0 * 1)=35$. A company with two non-compliances, one classified as Type 0 and the other classified as Type 3 has a $C G \mathscr{G}$ Disclosure Index of $(5 * 6)+(0 * 1)+(3 * 1)=33$. In calculating the $C G \&$ E Disclosure Index all the provisions are equally weighted because the Combined Code considers each provision to be equally important. Nevertheless, we also run separate regressions for each provision.

Our $C G \mathscr{E}$ Disclosure Index follows the well established methodology in the finance and accounting literature (e.g., Gompers et al., 2003; Klapper and Love, 2004; Bebchuk et al., 2009; Khanna et al., 2004; Durnev and Kim, 2005; Aggarwal et al., 2009) that uses a check-list of corporate governance aspects regarding specific provisions a company adopted (e.g., the Antitakeover Index, the ISS Index) or the level of disclosure (e.g., the S\&P Transparency and Disclosure Rankings, the CIFAR Index). The important difference is that our $C G \mathscr{E}$ Disclosure Index is not limited to a one-size-fits-all approach to corporate governance, nor to the quantitative assessment of governance disclosure, but it is also a qualitative indicator of the value of that information. Furthermore, by looking at both aspects of compliance with standards and disclosure quality, our $C G \&$ Disclosure Index captures their interrelated impact on the overall corporate governance quality of a company, without limiting itself to one single governance aspect. Robustness tests of the $C G \& \mathcal{G}$ Disclosure Index are shown in Section 4.3.2.

Panel A of Table 1 provides summary statistics of corporate governance characteristics. Of the total 1275 company-year observations, we have 860 cases $(68 \%)$ of lack of compliance with all the 
provisions of the Code. The average number of non-compliances is 1.2 per company, and 1.8 within the subset of non-compliant companies only. There are 198 instances where companies do not provide any explanation for at least one of their non-compliances. The average $C G \&$ Disclosure Index is 36.39 for the whole sample and the median is 37 . The average $C G \mathscr{E}$ Disclosure Index for the sub-sample of noncompliant companies is 34.65 , with a median of 36 . The minimum value of the $C G \mathscr{G}$ Disclosure Index is 10 and the maximum is 40.

In a companion paper (Arcot, Bruno, and Faure-Grimaud, 2010), we provide more detailed statistics on the corporate governance characteristics, which we briefly discuss, but do not report in tables for space reasons. There is a constant increase in the propensity to comply with the provisions over time. By the end of 2004, more than half of the companies (56\%) in the sample are fully compliant with the Code, as compared to $10 \%$ in 1998 . The average CG \& Disclosure Index increases over the period from 36 to 38 (Chart 1). The average number of non-compliances per company decreases monotonically from 2.05 to 1.57 in 2004 . More worrying, an average $17 \%$ of non-compliances are not explained at all. In 55 cases, non-compliant companies have the highest $C G \&$ Disclosure Index value of 40. Typically, companies either stick to the same explanation across years or comply. Non-compliant companies with the $C G \mathscr{E}$ Disclosure Index greater than 37 have mainly (85\%) one non-compliance classified as Type 3 or above.

\subsection{Financial and Ownership Data}

We use the industry-adjusted return on assets $(R O A)$ as our main measure of performance since we are interested in investigating how heterogenous corporate governance choices reflect on the efficient use of the company assets. We also focus our analysis on operating performance rather than stock market performance because we do not know the exact day corporate governance announcements are made public; also, public information about governance may not be impounded in stock prices in a timely manner (see Core et al., 2006), whereas weak corporate governance is associated with an inefficient use of company's resources that leads to poor operating income. As discussed in Barber and Lyon (1996) and Core et al. (2006), return on assets is a preferred measure of operating 
performance because it is not affected by leverage, extraordinary items, and other discretionary items; it has also more desirable distributional properties than return on equity. We define the return on assets as the ratio of earnings before interests and taxes (EBIT) to total assets. We then compute the industry-adjusted measure by subtracting the return on assets of each company in each year with the median return on assets of its respective Fama-French industry group. Accounting information comes from Worldscope, whereas monthly stock market data is from Datastream.

Ownership data is downloaded from Thomson One Banker (Ownership Module). Following Dahya, Dimitrov, and McConnell (2008), companies are divided between individually-owned and widely-held based on the dominant shareholder at the $10 \%$ threshold. A firm has a dominant family shareholder if an individual, family, or privately held firm owned by an individual or family, owns at least $10 \%$ of the voting rights in the firm. We construct a dummy (Family Ownership) that takes the value one if a company has a dominant family shareholder and zero otherwise. ${ }^{9}$ Since $10 \%$ of voting rights is frequently sufficient to exert control, this cut-off is used extensively (e.g., La Porta et al., 1999). If ownership data is not available for a particular company in Thomson One Banker, we hand-collect information from Hemscott's Corporate Register.

We also use in the analysis the following variables that have been used in similar studies investigating the determinants of corporate governance choices and their performance impact: the logarithm of book value of assets (Size) or of the market value of assets (Market Capitalization), the logarithm of firm age (Age), the logarithm of the ratio of market to book value of equity (Growth Opportunities), the ratio of long term debt to total assets (Leverage), the ratio of EBIT to sales (Profitability), and the ratio of property, plant and equipment (PPE) to sales (Capital Intensity) ${ }^{10}$.

Panel B of Table 1 shows some financial characteristics of our sample. Since the companies belong to the FTSE350 index they are, on average, profitable in terms of ROA (4.93\%), large (assets of GBP 3670 millions), relatively old (40 years old) and not highly levered (0.19). We have 204 cases related to the presence of family firms (17\% of the sample) which is consistent with the summary statistics reported in Faccio and Lang (2002) relative to the sample of companies (large)

\footnotetext{
${ }^{9}$ We also checked for the presence of dual-class shares and pyramid structures, with unchanged results.

${ }^{10}$ Due to the presence of significant outliers, we winsorize the ratio PPE to sales at the $1 \%$ level.
} 
we consider in our analysis.

\section{Multivariate Results: Corporate Governance Structure and Dis- closure}

\subsection{Determinants of the Corporate Governance Structure}

We investigate what types of companies are more likely to comply with the corporate governance standards and what types of companies deviate. We use a logit estimation and we regress the variable Dummy CG Deviation on various company characteristics that may be associated with corporate governance choices and board structure.

Different corporate governance arrangements may be justified for monitoring reasons. Since large shareholders have the incentive to collect information and the power to monitor managers (Shleifer and Vishny, 1986; Bolton and Von Thadden, 1998), they substitute the monitoring role of the board. When the principal is informed, he can exercise formal authority (the right to decide) and choose the project that he prefers (Aghion and Tirole, 1997). It is therefore more likely that firms with concentrated family shareholders comply less with provisions related to the monitoring role of the board, for instance appointing fewer outside and independent directors, because the presence of family shareholders alleviates free-riding problems in the monitoring process. We therefore use a dummy (Family Ownership) identifying family firms.

Raheja (2005) and Adams and Ferreira (2007) also argue that board structure is determined by different monitoring and advising needs generally related to operational characteristics and the industrial environment. When the costs of monitoring are high, for instance in the presence of projects with future high growth opportunities whose cash flows are costly to verify, shareholders may optimally elect friendlier boards to encourage the CEO to share information; also, companies can decide to offer specific contracts and compensation arrangements to retain managers for firms in which firm-specific knowledge is important. As in Boone et al. (2007) and Linck et al. (2008), 
we use the logarithm of the market to book ratio to measure Growth Opportunities. ${ }^{11}$

In addition, Coles et al. (2007), Lehn et al. (2005), Boone et al. (2007), and Linck et al. (2008) argue that board structure is driven by the scope and complexity of the firm's operation (e.g., larger companies may need bigger boards or more advice by outside directors). We follow Boone et al. (2007) and Linck et al. (2008) and we use the logarithm of the market value of equity (Market Capitalization) and firm age (Age) as proxies for firms' scope.

Finally, we use Profitability, Leverage, and Capital Intensity to proxy for other forms of monitoring that can substitute the role of the board. In fact, highly levered firms that depend on external resources may be differently monitored; firms operating with higher proportions of intangible assets may find it optimal to adopt stricter governance mechanisms to signal to investors that they intend to prevent the future misuse of these assets; and low profitability can be associated with higher private benefits and weaker boards. We also use industry dummies to control for possible externalities at the industry-level. Regression standard errors are robust and clustered at the firm-level.

The results presented in Table 2, column 1, show that companies with a dominant family shareholder and those with growth opportunities are more likely to deviate from the corporate governance standards. There is unconvincing evidence that the size of a company is a major factor in the corporate governance choices: the value of assets (Market Capitalization) is not significant, whereas Age is positive. Profitability, Leverage, and Capital Intensity coefficients are not significant.

We further disentangle Dummy $C G$ Deviation into its various components to understand what specific corporate governance standards companies are more likely to deviate from (columns $2-7) .{ }^{12}$ We first construct two broader dummy indicators grouping common characteristics related to the board composition and committees:

\footnotetext{
${ }^{11}$ Market to book ratio is a widely recognized proxy for Growth Opportunities (see, amongst others, Kayhan and Titman, 2007; Hovakimian, Hovakimian, and Tehranian, 2004; Goyal, Lehn, and Racic, 2002), which are typically more costly for outsiders to monitor and verify than are assets in place. Differently from other studies on US companies (e.g., Coles, Daniel, and Naveen, 2008), we are unable to use R\&D expenses as an alternative proxy for costly monitoring of growth/investment opportunities because of a large number of missing observations in Worldscope (55\% of the sample).

${ }^{12}$ We construct aggregate indicators instead of using separately each of the eight provisions constituting Dummy $C G$ Deviation because in the logit estimation some dummies perfectly predict the outcome and we would lose many observations due to the small number of non compliances within each provision.
} 
- Dummy Board equal to 0 if the company is compliant with the provisions related to the separation of CEO/Chairman (A.2.1), existence of a senior non executive director (A.2.1), proportion of non-executive (A.3.1) and independent directors (A.3.1), and 1 if it is not compliant with at least one of these provisions;

- Dummy Committees $\&$ Contracts that takes a value 0 if a company is compliant with the provisions related to the nomination, compensation and audit committees (A.5.1, B.2.2, D.3) and the terms of service contracts (B.1.7), and 1 otherwise.

We then construct finer dummy indicators by grouping subsets of provisions most likely to be interrelated or jointly determined, to better disentangle the corporate governance choices of the companies:

- Dummy Power equal to 0 if a company is compliant with both the provisions related to the separation of CEO/Chairman (A.2.1) and the existence of a senior non executive director (A.2.1), 1 otherwise;

- Dummy Non-Executives equal to 0 if a company is compliant with both the provisions related to non-executive presence (A.3.1) and independent directors (A.3.1), and 1 otherwise;

- Dummy Remuneration equal to 0 if a company is compliant with both the provisions related to the compensation committee (B.1.7) and service contracts (B.1.7), and 1 otherwise;

- Dummy Transparency equal to 0 if a company is compliant with both the provisions related to the nomination (A.5.1) and audit committees (D.3).

We find that companies with a dominant family shareholder are more likely to be noncompliant with provisions related to the monitoring role of the board (column 2); in particular, they are more likely to have greater concentration of power in the board (column 4), to be less monitored by independent and outside directors (column 5), and to have less transparent nomination and audit committees (column 6). Companies with growth opportunities are more likely to be noncompliant 
with governance aspects related to both board composition (more concentration of power (column 4)) and board committees (audit, nomination, and compensation (columns 6 and 7)).

These results are consistent with the monitoring role of the family shareholder who can be more informed about company projects and monitor the CEO more efficiently, thus relying less on monitoring from the non-executive board members. Family shareholders also tend to retain formal authority in audit and nomination issues, which reflects their discretion in the management of the company. The results for the companies with high growth opportunities suggest that such companies will have a greater concentration of power at the CEO/Chairman level and they prefer to retain flexibility in the contracts, terms and appointment of new board members given their dynamic and firm-specific characteristics. Similar to Boone et al. (2007), we do not find significant evidence that the proportion of independent and outside directors is related to the costs and benefits of monitoring.

\subsection{Determinants of Corporate Governance Disclosure}

Since the decision of deviating from the governance standards is not necessarily a signal of bad governance because companies may deviate for valid and good reasons, we turn our attention to the informativeness of the explanations companies provide. We perform a multinomial logit regression to analyze what factors affect the decision to deviate from the governance standards jointly with the level of explanation provided, since the two decisions occur in sequence. To do so, we have to construct a set of dummy variables that capture the degree of governance disclosure of companies.

We start with "extreme cases", i.e. companies that omit any type of explanation (Type 0) when departing from the governance standards and those that, on the contrary, give narrative and detailed explanations (Type 5). We create a dummy No Disclosure equal to 1 if no explanation is provided regardless of the number of non compliances and 0 otherwise, and a dummy Full Disclosure equal to 1 if all explanations are fully informative and 0 otherwise. ${ }^{13}$ We then look at "intermediate" cases, i.e. situations where some information is disclosed but it is not fully informative. We

\footnotetext{
${ }^{13}$ There are 55 company-year observations with all Type 5 explanations and 198 with at least one Type 0 explanation.
} 
create two dummies, Some Disclosure that takes 1 if $C G \&$ Disclosure Index is above the median and 0 otherwise, and Poor Disclosure equal to 1 if $C G \&$ Disclosure Index is below the median and 0 otherwise. These four dummies capture different degrees of informativeness, hence governance disclosure quality. The group of compliant companies is the reference dummy group. The multinomial regression is run on a set of company-level variables defined before (Family Ownership, Growth Opportunities, Market Capitalization, Age, Profitability, Leverage, and Capital Intensity), with industry dummies and robust standards errors clustered at the firm level.

Table 3 shows the multinomial logit results. Not surprisingly, companies with a dominant family shareholder are more likely to deviate from the governance standards and to omit (No Disclosure, $\mathrm{p}$-value $=0.06)$ or give poor explanations $($ Poor Disclosure, $\mathrm{p}$-value $=0.07)$ for their non-compliances. This evidence is consistent with the existent literature showing less governance disclosure by concentrated family ownership because families behave more like insiders and have less incentives to disclose public information (Ajinkya, Bhojraj, and Sengupta, 2005; Anderson, Duru, and Reeb, 2008; Chen, Chen, and Cheng, 2008). In fact, because families are actively involved in the management, the information asymmetry between owners and managers is lower and the family shareholder prefers less public disclosure.

We also find that companies with growth opportunities, that we already knew from the evidence before tend to comply less, do not significantly differ in the disclosure quality, whereas older companies are more likely to comply less and explain little. We obtain similar results when we use a finer classification of the quality of disclosure (results not shown). ${ }^{14}$

\footnotetext{
${ }^{14}$ We construct six dummy variables, each equal to 1 (and 0 otherwise) if the worst explanation given (among multiple non compliances) is Type 0 or Type 1 or Type 2 or Type 3 or Type 4 or Type 5 , respectively. The compliant companies are the reference dummy group. We again find that the presence of a family shareholder is related to higher probability of non compliance and lack of explanations, whereas companies with growth opportunities comply less but do not differ in the disclosure quality. In addition, we also run the multinomial specification with only three dummy groups (Poor Disclosure, Some Disclosure and compliant companies) with similar results.
} 


\section{Multivariate Results: Corporate Governance, Disclosure, and Performance}

In this section, we investigate the effects of different corporate governance choices and disclosure on performance to differentiate between specific company characteristics (one-size-does-not-fit-all hypothesis) and self-serving goals (expropriation hypothesis). On the one hand, companies may adhere or deviate from governance standards in light of their unique circumstances and characteristics. For instance, some companies may prefer friendly boards to retain flexibility in some decisions, like executive contracts and compensation, due to the complexity of their projects and activities or because the monitoring and disciplining role is exercised by the dominant shareholder.

On the other hand, deviations from commonly recognized standards of good practice in corporate governance may lead to potential entrenchment and private benefit expropriation. When observing poor (or lack of) governance transparency, shareholders may conjecture the worst in terms of governance (e.g., entrenchment, private benefits of control and minority expropriation) because either companies do not want to or cannot disclose inappropriate governance information.

Both adherence to corporate governance standards and better disclosure of non-compliances lead to less information asymmetry and facilitate monitoring of potential self-interested behavior. The role of governance standards and of disclosure quality thus contribute directly to performance by disciplining management, promoting better use of the assets in place, better project selection, and reduced expropriation of investors' wealth (Shleifer and Vishny, 1997; Bushman and Smith, 2003).

\subsection{Base Analysis}

To provide an initial assessment of the associations between corporate governance and performance, we compare ROA across various subsamples of firms. Table 4 presents the univariate results. Panel A indicates that there is no statistical difference in the average ROA between com-

pliant and noncompliant companies $(5.26 \%$ versus $4.76 \%, \mathrm{p}$-value $=0.40)$. Panels $\mathrm{B}, \mathrm{C}$, and $\mathrm{D}$ 
show the differences in average ROA between compliant companies and companies with a different number of non-compliances. We do not observe a clear pattern: fully compliant companies are not statistically different from companies with just one noncompliance $(5.26 \%$ versus $5.35 \%$, p-value $=0.89)$; compliant companies outperform those with two non compliances $(5.26 \%$ versus $3.63 \%$, p-value $=0.041)$, but do not perform better than those with three non compliances $(5.26 \%$ versus $4.88 \%, \mathrm{p}$-value $=0.69)$. This evidence suggests that compliance may not necessarily lead to higher operating performance.

Panel $\mathrm{E}$ of Table 4 shows that companies with the $C G \mathscr{E}$ Disclosure Index above the median are associated with a higher ROA than companies with $C G$ E Disclosure Index below the median (5.63\% versus $4.26 \%$, $\mathrm{p}$-value $=0.014)$. A similar result is obtained for the sub-sample of noncompliant companies: noncompliant companies with $C G \mathscr{E}$ Disclosure Index greater than their sample median (36) have a better ROA than those below the median $(5.84 \%$ versus $4.04 \%$, p-value $<0.01)$. These preliminary results suggest that companies that either comply with the Code recommendations or those that do not comply for valid reasons have better operating performance than companies departing from best practice and providing ambiguous reasons.

In a multivariate setting, we then run the following OLS regression:

$$
R O A_{i, t+1}=\alpha+\beta \cdot C G_{i, t}+\delta \cdot \text { Controls }_{i, t}+\varepsilon_{i, t},
$$

where $R O A$ is the next year industry-adjusted ROA, and $C G$ is a vector of governance variables (No Disclosure, CG \& Disclosure Index, \# CG Deviations, Dummy CG Deviation) as previously defined. We use future performance to reduce endogeneity issues. The regression is run with time dummies and robust standard errors clustered at the firm level. We cannot include company dummies because corporate governance indicators are mostly invariant over time. The explanation provided in cases of noncompliance, and hence the $C G \& \&$ Disclosure Index, also tends to remain the same over time. We use size, growth opportunities, leverage, current profitability and capital intensity as control variables, those most likely related to a company's future performance and that 
have been found in the literature to explain the cross-sectional and time-series variation in ROA (Klapper and Love, 2004; Dahya and McConnell, 2007). We also control for the presence of large shareholders to verify that the performance results are not driven by ownership characteristics of the company (Claessens et al., 2002).

Table 5, columns 1 and 2, shows that companies omitting any type of explanation (Dummy No Disclosure) on average have a $1.4 \%$ and $1.6 \%$ lower ROA than all the other companies, including and excluding fully compliant companies respectively. This is consistent with the hypothesis that omitting corporate governance information is associated with agency problems and private benefits extraction. Table 5, column 3, shows that the coefficient of $C G \&$ Disclosure Index has a positive (0.0014) and statistically significant (at 5\% level) relationship with performance. The economic magnitude of the relationship is high: one standard deviation increase in the $C G$ \& Disclosure Index is associated with an increase in ROA by 0.0067 , a $1.7 \%$ increase relative to the sample average of $4.91 \%$. The positive relationship is further confirmed among the sub-sample of noncompliant companies only (column 4): the coefficient of the $C G \& \mathcal{E}$ Disclosure Index is positive (0.0021) and significant at the $1 \%$ level. This evidence highlights that adherence to governance standards and better disclosure quality are positively associated with performance, thus confirming that transparency in the governance practices is associated with a better and more efficient use of the resources. Overall, these results are consistent with the literature showing that better governance standards and disclosure will reduce management's consumption of private benefits of control and self-serving goals (e.g., Klapper and Love, 2004; Bens and Monahan, 2004; Durnev and Kim, 2006; Hope and Thomas, 2008).

Table 5, columns $5-7$, provides additional evidence on the consequences of deviating and not explaining. There is no significant evidence that the deviation from corporate governance standards is associated with lower performance. The coefficient of the index constructed by counting the total number of non-compliances (\# CG Deviations) is not significantly associated with performance: the sign is negative as expected, but it is not significant ( $\mathrm{p}$-value $=0.44$, column 5 ). The separation of companies between compliant and noncompliant (Dummy CG Deviation) does not 
reveal a significant relationship between corporate governance and performance: the coefficient is negative $(-0.0025)$ but not significant $(\mathrm{p}$-value $=0.76)($ column 6$)$. These results could be related to the fact that good corporate governance is not simply a matter of complying with practices, but companies endogenously choose their corporate governance structure; hence there should not appear any significant association with performance. However, when we interact the Dummy CG Deviation with $C G \&$ S Disclosure Index (capturing the quality of disclosure in the absence of full compliance) we find that the coefficient of the variable Dummy CG Deviation is negative $(-0.067)$ and significant ( $\mathrm{p}$-value $=0.015$ ), whereas the coefficient of the incremental effect of $C G \mathscr{E}$ Disclosure Index is positive $(0.002)$ and significant $(\mathrm{p}$-value $=0.006)$ (column 7$)$. This result confirms that the quality of governance disclosure is positively correlated to performance, which corroborates that the positive relationship between heterogeneous corporate governance choices and performance is limited to those companies with higher levels of governance transparency.

Table 5, columns 8 to 11, confirm that the previous results are robust to the inclusion of a dummy variable capturing the presence of a family shareholder (Family Ownership) on performance. Companies omitting explanations (No Disclosure) have lower ROA (p-value $=12 \%$ and $\mathrm{p}$-value $=8 \%$ for the all sample and noncompliant companies only, respectively). Also CG $\mathcal{G}$ Disclosure Index retains its significance ( $\mathrm{p}$-values $=8 \%$ and less than $1 \%$, respectively) and magnitude when controlling for ownership. The coefficient estimates of Family Ownership and its interaction with the corporate governance indicators (No Disclosure * Family Ownership or CG $\&$ Disclosure Index * Family Ownership) are never statistically significant. Also the F-tests of the coefficients sum of Family Ownership and its interaction with corporate governance [(Family Ownership + No Disclosure * Family Ownership) or (Family Ownership + CG $\mathscr{G}$ Disclosure Index * Family Ownership)] are not statistically significant. This evidence suggests that the performance estimations are not driven by ownership characteristics and that non-compliant governance practices and low disclosure are associated with negative performance effects for both family and non-family companies. Overall, we interpret these results to suggest that adherence to governance practices and higher disclosure play an important role in alleviating agency problems and that the presence of a family shareholder 
does not seem to have an incremental significant effect. These results are consistent with the conflicting evidence found in the family firms literature about the positive monitoring effects versus the negative expropriating effects of family firms on performance.

\subsection{Individual Corporate Governance Provisions}

So far, we have focused on a governance index that comprises all corporate governance recommendations of the Code. We now focus on each individual governance provision to investigate what aspect matters most for performance. For each provision, we construct a dummy that takes the value of 1 if a company does not comply with that provision and 0 otherwise (Dummy CG Deviation Provision), a dummy that takes the value of 1 if a company does not provide an explanation for its non-compliances (No Disclosure Provision), and a governance index based on both compliance and explanation (CG \& Disclosure Provision). For instance, a company with a separate CEO/Chairman has the same $C G \&$ Disclosure Provision Index (5) as a company with a combined CEO/Chairman and providing a valid explanation (Type 5). We then run separate regressions of the main specification (2), with all the control variables, time dummies and clustering at the company-level. Each cell in Table 6 reports the coefficient estimates of each different provision.

Column 1 shows that compliance with the provision recommending non-executive directors in the board in the proportion of at least one third is significantly associated with better performance, consistent with the evidence found in Dahya and McConnell (2007). We do not find that companies with separate $\mathrm{CEO} /$ Chairman have better performance, consistent with the existing mixed evidence on the importance of splitting the two roles for performance. We also do not find that a majority of independent directors is associated with better performance, in line with the current debate on the lack of expertise of many independent outside directors and their effective impact on performance.

Columns 2 and 3 show the results for provisions when the non compliance is not explained. We find that No Disclosure Provision is negative and significant for the provisions related to the presence of at least one third non executive directors in the board, the majority of independent non-executive directors, the presence and independence of the remuneration committees. We find 
similar significant results in case of the $C G \& 6$ Disclosure Provision (columns 4 and 5) where the quality of noncompliance explanations are taken into account. Additionally, the $C G \&$ Disclosure Provision is positive and significant for the provision related to the presence and independence of the audit committee. These results are consistent with the evidence found in the literature on the trade-off between the costs and benefits of having independent non executive directors and board committees. A company that, after evaluating the costly effects of appointing new directors and constituting independent committees, opts out from the governance recommendation for a valid reason is associated with higher performance than a company opting out and not explaining.

\subsection{Robustness Tests}

\subsubsection{Endogeneity}

Endogeneity concerns are endemic in the corporate governance literature. If companies optimally decide to comply or not to comply with the governance standards, then we should not observe any relationship with performance. The UK system allows us to tackle this aspect of the endogeneity problem because we can analyze the reasons why a company depart from governance standards, thus differentiating between value-maximizing and self-serving decisions. Moreover, companies for which the governance standards are not optimal are not incentivized to go private as a result of the sub-optimal mandatory governance structures, and we can observe their governance decisions. Other possible concerns could be related to unobserved factors that are driving both governance and performance (Hermalin and Weisbach, 2003). For example, a growing firm with a large need for outside financing may have more incentives to adopt better governance standards and disclosure in order to lower its cost of capital, thus inducing a positive correlation between governance and performance.

We address endogeneity concerns in several ways. First, in our regressions we investigate the relationship between the current governance structure with future (next year) operating performance. Second, we add several control variables that proxy for specific firm characteristics (ownership, size, growth opportunities, leverage, and capital intensity) and find that our governance results are not 
spuriously caused by these omitted variables. ${ }^{15}$

We further deal with endogeneity by taking advantage of our panel data structure and we perform GMM difference estimations (also used in a similar setting by Chhaochharia and Laeven, 2009). We estimate a dynamic model using the GMM difference estimator developed by Arellano and Bond (1991). This model uses the lag of the dependent variable as an additional explanatory variable. All the other explanatory variables including the dummy No Disclosure and the $C G \mathscr{E}$ Disclosure Index are treated as predetermined variables and we use all available lags as instruments. The results of the estimation are reported in Table 7, columns 1 to 4 . In line with our earlier findings, lack of corporate governance disclosure (No Disclosure) is associated with poor performance, whereas more governance transparency, in the form of adhering to higher standards or better disclosing ( $C G \& \mathcal{E}$ Disclosure Index), is positively and significantly related to operating performance.

Finally, we deal with endogeneity issues by instrumenting the endogenous variable $C G \mathscr{E}$ Disclosure Index and running 2SLS estimations. A good instrument would be correlated with the endogenous variable but uncorrelated with the error term in the structural equation. In choosing our instrument, we follow the existing corporate governance literature (e.g., Aggarwal, Erel, Stulz, and Williamson, 2009; John, Litov, and Yeung, 2008) and we use the average CG \& Disclosure Index of firms in the same industry, based on Fama-French industry groups and year, which captures industry factors explaining corporate governance. ${ }^{16}$ Since our dependent variable measure (ROA) is already adjusted for industry effects, it is reasonable to assume that the instrument is not correlated with the error term. We look at the first stage regression to detect whether there is a weak instrument problem (results not reported). The instrument coefficient estimate shows a positive and significant (at 1\%) relationship, while the partial F-statistic test (Kleibergen-Paap Wald F-test) is 14.46. Based on the analysis by Stock et al. (2002) we can reject the null hypothesis of weak instruments. We therefore complete the 2SLS approach by estimating the second-stage.

\footnotetext{
${ }^{15}$ Another possible method is to include firm fixed effects, but this is not appropriate in our case because the $C G$ 83 Disclosure Index and the other corporate governance indicators are mostly invariant over time.

${ }^{16}$ We exclude industries with only one company observation. Our results are robust also to the exclusion of industries with less than five companies.
} 
The second-stage results are reported in Table 7, columns (5) and (6) for the whole sample and for the subsample of noncompliant companies, respectively. We find that $C G \& \mathcal{E}$ Disclosure Index is still significant at the $5 \%$ and $1 \%$ levels, respectively, confirming the relationships observed in Table 5 .

With the usual caveats in mind, the above tests give us some confidence in limiting concerns about endogeneity when interpreting the causal relationship between operating performance and corporate governance.

\subsubsection{Robustness of the Corporate Governance Index}

Notwithstanding that the $C G \& \mathcal{E}$ Disclosure Index contains some form of subjectivity based on the analysis of quality of the explanations which cannot be entirely eliminated, we perform the following robustness tests and alternative constructions of the index. First, we asked three graduate students to classify the explanations based on the 6-Types taxonomy described in section 2.1.2. We provided them with a spreadsheet containing the list of the exact explanations given by each company in cases of noncompliance and we told them to rank these based on the existence of specific and verifiable information related to the company's circumstances. We told them to give the maximum points to explanations that are unique to the company and to start deducting points the less specific the explanation. To avoid any bias in their classification, we did not give them examples of how we classified the explanation, nor did we describe our research hypothesis to them. Each student separately constructed the $C G \&$ G Disclosure Index for each company; we then took the average of the three scores $(C G \& \mathcal{G} \text { Disclosure- } R A)^{17}$ to estimate our base regression (2). Table 8 , columns 1 and 2, shows that the coefficients of the $C G \mathscr{E}$ Disclosure- $R A$ estimated by the research assistants are very similar to ours estimated in Table 5: the coefficient estimated on the entire sample is actually slightly bigger and more significant $(\mathrm{p}$-value $=0.03)$. This evidence highlights that the classification of the explanations is easily replicable on the basis of information publicly available to all shareholders and it makes us less concerned about possible biases.

\footnotetext{
${ }^{17}$ The maximum (minimum) value of $C G \mathscr{E}$ Disclosure- $R A$ is 40 (8.67), with a mean of 36.68 , a median of 37.67 , and a standard deviation of 4.67 .
} 
We next check that the results are not sensitive to the particular Type-scale used. We rescale the Types of the explanations using a narrower 3-Types scale classification solely based on the verifiability of the information, which also makes our classification less subjective. Non-compliances without any explanation continue to be classified as Type 0 and get zero points. General and not verifiable explanations (Types 1,2, and 3) get one point. Transitional situations (Type 4) and genuine explanations (Type 5) are all verifiable and are given two points. We then use the same methodology (1) to generate a rescaled corporate governance index ( $C G$ E Disclosure-Rescaled $).{ }^{18}$ Table 8, columns 3 and 4, shows that the results are robust to the use of a different scaling criteria, for both the whole sample and the subsample of noncompliant companies at the $5 \%$ and $1 \%$ level, respectively. As expected, the magnitude of the coefficient estimated is bigger because the scale is narrower, but the magnitude of the economic impact is similar.

In Table 8 , columns 5 and 6 , we further explore the issue of objectivity in the quantification of our disclosure quality index by constructing the ratio of the number of pages of the corporate governance section over the total number of pages of the annual report (CGPage-Ratio). This measure is admittedly crude and likely to be noisy, but it gives indications of the care and importance companies take when reporting on their corporate governance situation. ${ }^{19}$ We find that companies with corporate governance sections relatively smaller are significantly associated with lower ROA, which confirms the importance of the quality and detail of the corporate governance report as proxy for a serious commitment to corporate governance. ${ }^{20}$

Finally, we use the Standard and Poor's (S\&P) disclosure scores as an alternative measure of disclosure quality. The S\&P score is an objective measure based on $2001-02$ annual reports of the companies. The S\&P score counts whether a firm discloses relevant information on 91 possible items that would be of interest to investors: ownership structure and investor relations (22 items),

\footnotetext{
${ }^{18}$ Under the narrower classification, the maximum (minimum) value of $C G \&$ E Disclosure-Rescaled is 16 (5), with a mean of 14.87 and a standard deviation of 1.61

${ }^{19}$ We loose 16 observations due to lack of the data on the total number of pages of the complete annual report. The maximum (minimum) value of CGPage-Ratio is $38.5 \%(0.9 \%)$, with a mean of $3.9 \%$, a median of $3.6 \%$, and a standard deviation of $1.8 \%$.

${ }^{20} \mathrm{We}$ also counted the total number of words of the explanations provided when departing from best practice. The length of the explanation is however not significantly associated with performance, possibly highlighting a difference between long but obscure explanations and more concise but serious and verifiable explanations.
} 
board and management structure and process (34 items), and board and management structure and process (35 items). The score of the three categories are summed to create an aggregate composite disclosure score by assigning an equal weight to each disclosed item, with a higher score representing more transparency and disclosure. We merge our sample of companies with the S\&P dataset to get a total of 81 companies for which we have both details of compliance with the Code and S\&P disclosure scores. We then replicate the specification in Table 5, column 7 , in a crosssection framework, by replacing our measure of disclosure based on the quality of explanations with the S\&P disclosure index. Table 8, column 7, shows that our previous results are confirmed when using an alternative and objective measure of disclosure, specifically that noncompliant companies have better performance the more they disclose.

\subsubsection{Stock Market Returns}

In addition to ROA as measure of performance, we test whether compliance with the Code provisions and better quality explanations show up with an increase in stock prices. The event study methodology is a common technique used for such an investigation. We are however unable to carry out an event study because we do not know the exact day a corporate governance decision is taken. Typically, such decisions are taken by companies throughout the year and announced immediately to the market, whilst we capture such information only from the companies' annual reports, which are usually published $4-6$ months after the financial year-end. Hence, our analysis would suffer from measurement errors.

To overcome these problems, we use the long run event study methodology used by Gompers et al. (2003). We first separate companies into two portfolios based on the respective governance parameter. We construct the portfolios and calculate their value-weighted returns from July of year $t$ to June of year $t+1$ based on a corporate governance aspect as at the end of calendar year $t-1$. We perform this analysis for a six year period from July 1999 to June 2005 and we begin in July 1999 since we have compliance data from December 1998 onwards. The portfolios are reset in July of every year based on compliance at the end of the last calendar year. We then estimate the 
following Fama-French (1993) three-factor model:

$$
R_{t}=\alpha+\beta_{1} \cdot R M R F_{t}+\beta_{2} \cdot S M B_{t}+\beta_{3} \cdot H M L_{t}+\varepsilon_{t}
$$

where $R M R F, S M B$, and $H M L$ are the monthly Fama-French factors for the UK representing the market, size, and book-to-market factors, respectively. We calculate the Fama-French factors based on all listed UK companies from Datastream, following the Fama-French (1993) methodology. $R_{t}$ is the excess return in month $t$ from a strategy involving going long and short in portfolios of companies with specific corporate governance characteristics. The alpha in this model can be therefore interpreted as the monthly abnormal return in excess of what could be achieved by passive investment in these factors. If we observe a positive and significant alpha after controlling for the market, size, and book-to-market factors, then the specific governance parameter is not incorporated in the stock prices.

Panel A of Table 9 shows the results where the dependent variable, $R$, is the monthly return difference between the portfolios consisting of only compliant and noncompliant companies. Thus, the alpha in this estimation is the abnormal return on a zero-investment strategy that buys fully compliant companies and sells companies that are not fully compliant. We do not find statistically significant evidence that compliant companies outperform noncompliant companies.

We also form portfolios based on the $C G \& \mathcal{G}$ Disclosure Index, i.e., we go long in the high score portfolios and short in the low score portfolio. We use the median of the $C G \&$ Disclosure Index (37) as the cutoff and we estimate the Fama-French model using monthly value-weighted returns obtained by going long in the high Index portfolio and shorting the low Index portfolio. Panel B of Table 9 shows that the alpha is positive $(0.01)$ and significant (p-value $=0.07$ ), and highlights that companies complying with the Code recommendations or have valid explanations for not complying outperform all others by $1 \%$ on average per month. This evidence on stock market returns complements the previous results on operating performance. ${ }^{21}$

\footnotetext{
${ }^{21}$ We however do not find that companies omitting explantions significantly underperform all others. We interpret this as possible evidence that investors interpret silence negatively (no news is bad news) (Hollander, Pronk, and Roelofsen, 2010). The stock price may immediately reflect this belief.
} 


\subsubsection{Agency Costs}

The preceding evidence establishes an empirical relationship of corporate governance with operating performance and stock market returns. In this section we perform a direct test, similar to Gompers, Ishii, and Metrick (2003), that lack of transparency and deviation from governance practices cause an increase in agency costs through inefficient investments. A substantial literature, dating back at least to Williamson (1964), holds that managers may undertake inefficient projects in order to extract private benefits. When governance transparency is reduced, the agency costs hypothesis predicts that managers can make suboptimal self-maximizing decisions, including "empire building", which decrease operating performance (Jensen, 1986, Diamond and Verrecchia, 1991, Titman, Wei, and Xie, 2004).

If better corporate governance reduces moral hazard, it can then improve efficiency by increasing shareholder ability to monitor managerial activities. For instance, Gompers, Ishii, and Metrick (2003) find that companies adopting less takeover defences are associated with lower capital expenditures. Biddle, Hilary, and Verdi (2009) find that companies with higher quality financial reporting invest less. We therefore use the following median regression ${ }^{22}$ to investigate whether adherence to the governance standards and better quality of explanations provided in cases of noncompliance reduce the moral hazard problem:

$$
C A P E X_{i, t}=\alpha_{1}+\beta_{1} \cdot C G_{i, t}+\delta_{1} \cdot \text { Controls }_{i, t}+\varepsilon_{i, t}
$$

where $C A P E X$ is the industry adjusted ratio of capital expenditures to total sales constructed using the Fama-French industry group, $C G$ is a vector of governance variables (Dummy $C G D e$ viation, \# CG Deviations, CG \& Disclosure Index, No Disclosure) as previously defined. We use size, growth opportunities, leverage, and current profitability as control variables, since all these characteristics may be associated with capital expenditures decisions. Regressions are run with time dummies.

\footnotetext{
${ }^{22}$ We use the median regression due to a significative presence of outliers in the CAPEX variable.
} 
Table 10 shows that lack of disclosure is significantly associated with more moral hazard problems: companies omitting explanations have more capital expenditures (columns 1 and 2). On the contrary, $C G \&$ Disclosure Index is negatively and significantly associated with excess capital expenditure (columns 3 and 4). These results show that managers of well-governed firms, i.e., those that fully embrace the Code's recommendations or departure from best practice for valid reasons, are less likely to undertake wasteful projects. Finally, columns 5 and 6 show that full compliance with the Code and a lower number of non-compliances are not significantly associated with less moral hazard problems.

On the one hand, these results support the earlier evidence that compliance with the corporate governance standards and better disclosure alleviate agency problems and do not exacerbate moral hazard behavior. On the other hand, more opaque companies engage in a large amount of inefficient investment, which complements the earlier evidence: companies hiding the reasons for departing from corporate governance standards make self-maximizing decisions and undertake inefficient projects that reduce profitability and stock returns.

\section{Summary and Conclusion}

In this paper we have examined corporate governance choices along with their disclosure. Our analysis builds on an institutional setting where corporate governance standards are listed but not mandated and companies have flexibility in their governance choices.

We find that companies with a large shareholder (mainly families) and those with growth opportunities are more likely to deviate from the corporate governance standards, which is consistent with different monitoring needs of such companies. Family firms also tend to disclose less information about their governance choices. Only companies adhering to the governance standards or explaining the reasons of their different governance choices have better performance, whereas companies with self-serving goals are opaque about their corporate governance choices and this is reflected in lower performance. These results highlight that adherence to governance standards and better disclosure 
of the noncompliances act as substitute mechanisms to reduce agency costs.

Our empirical results are related to the recent literature that indicates that corporate governance and disclosure vary across firms depending on the characteristics of the firm. At the same time, the absence of mandated regulations and formal monitoring of disclosure gives discretion to companies, which some of them take advantage for self-maximizing purposes. For instance, our evidence that companies held by family shareholders are less inclined to governance transparency suggests that voluntary regulation may have drawbacks in countries with lots of family ownership. However, the question of whether mandatory regulation would help solving the agency conflicts and be preferred to voluntary regulation is left unanswered and for future research. 


\section{References}

[1] Adams, R., and D. Ferreira, 2007, A Theory of Friendly Boards, Journal of Finance, 62, 217-250.

[2] Adams, R. B., Hermalin, B. E. and Weisbach, M. S., 2010, The Role of Boards of Directors in Corporate Governance: A Conceptual Framework \& Survey, Journal of Economic Literature, $48,58-107$.

[3] Aggarwal, R., I. Erel, R. Stulz, and R. Williamson, 2009, Differences in Governance Practices between U.S. and Foreign Firms: Measurement, Causes, and Consequences, Review of Financial Studies, 22, 3171-3209.

[4] Aghion, P., and J. Tirole, 1997, Formal and Real Authority in Organizations, Journal of Political Economy, 105, 1-29

[5] Anderson, R, A. Duru, D. Reeb, 2009, Founders, heirs, and corporate opacity in the United States, Journal of Financial Economics, 92, 205-222.

[6] Ajinkya, B. B., S. Bhojraj, and P. Sengupta, 2005, The association between outside directors, institutional investors and the properties of management earnings forecasts, Journal of Accounting Research, 43, 343-376.

[7] Arcot, S. R. and V. G. Bruno, 2007, In Letter but not in Spirit: An Analysis of Corporate Governance in the UK, unpublished working paper, London School of Economics.

[8] Arcot, S.R., V.G. Bruno, and A. Faure-Grimaud, 2010, Corporate Governance in the UK: Is the Comply or Explain Approach Working?, International Review of Law and Economics, 30, 2, 193-201.

[9] Arellano, M., and S. Bond, 1991, Some Tests of Specifications for Panel Data: Monte Carlo Evidence and an Application to Employment Equations, Review of Economic Studies, 58, 277-297.

[10] Ball, R., A. Robin, and J. Wu, 2003, Incentives versus standards: properties of accounting income in four East Asian countries, Journal of Accounting and Economics, 36, 235-270.

[11] Barber B. M., J. D. Lyon, 1996, Detecting long-run abnormal operating performance: The empirical power and specification of test statistics, Journal of Financial Economics, 41, 359399

[12] Bebchuk, L.A., A. Cohen, and A. Ferrell, 2009, What Matters in Corporate Governance?, Review of Financial Studies, 22, 783-827.

[13] Bens, D., and S. Monahan, 2004, Disclosure Quality and the Excess Value of Diversification, Journal of Accounting Research, 421, 691-730.

[14] Biddle, G. C., G. Hilary, and R. Verdi, 2009, How Does Financial Reporting Quality Improve Investment Efficiency?, Journal of Accounting and Economics, 48, 112-131. 
[15] Bolton P., and E. Von Thadden, 1998, Blocks, liquidity and corporate control, Journal of Finance, 53, 1-25.

[16] Boone, A., L. C. Field, J. M. Karpoff, and C. G. Raheja, 2007, The Determinants of Corporate Board Size and Composition: An Empirical Analysis, Journal of Financial Economics, 85, 66-110.

[17] Bushman, R.M., and A.J. Smith, 2003, Transparency, financial accounting information, and corporate governance, FRBNY Economic Policy Review, 65-87

[18] Chen, S., X. Chen, and Q. Cheng, 2008, Do Family Firms Provide More or Less Voluntary Disclosure?, Journal of Accounting Research, 46, 499-536

[19] Claessens, S., S. Djankov, J.P. Fan, and L.H. Lang, 2002, Disentangling the incentive and entrenchment effects of large shareholdings, Journal of Finance, 57, 2741-2771.

[20] Coles, J. L., N.D. Daniel, and L. Naveen, 2008, Boards: Does one size fit all?, Journal of Financial Economics, 87, 329-356

[21] Committee on Corporate Governance, 1998, Final Report, Gee Publishing, London.

[22] Conyon, M. J. and S. I. Peck, 1998, Board control, remuneration committees and top management compensation, Academy of Management Journal, 41, 146-157.

[23] Core, J. E., 2001, A review of the empirical disclosure literature: discussion, Journal of Accounting and Economics, Volume 31, 441-456.

[24] Core, J. E., W. Guay and T. Rusticus, 2006, Does Weak Governance Cause Weak Stock Returns? An Examination of Firm Operating Performance and Investors' Expectations, Journal of Finance, 61, 655-687.

[25] Chhaochharia, V., and L. Laeven, 2009, Corporate Governance, Norms and Practices, Journal of Financial Intermediation, 18, 405-431.

[26] Dahya, J., J.J. McConnell and O. Dimitrov, 2008, Dominant Shareholders, Corporate Boards and Corporate Value: A Cross-Country Analysis, Journal of Financial Economics, 87, 73-100

[27] Dahya, J., J.J. McConnell and N. G. Travlos, 2002, The Cadbury committee, corporate performance and top management turnover, Journal of Finance 57, 461-483.

[28] Dahya, J., and J.J. McConnell, 2007, Board Composition, Corporate Performance and the Cadbury Committee Recommendation, Journal of Financial and Quantitative Analysis, 42, 535-564.

[29] Dedman, E., 2003, Executive turnover in UK firms: the impact of Cadbury, Accounting and Business Research, 33, 33-50.

[30] Diamond, D.W., and R.E. Verrecchia, 1991, Disclosure, Liquidity, and the Cost of Capital, Journal of Finance, 46, 1325-1359. 
[31] Durnev A., and E. H. Kim, 2005, To steal or not to steal: Firm attributes, legal environment and valuation, Journal of Finance 60, 1461-1493.

[32] Faccio, M., and L. H. P. Lang, 2002, The ultimate ownership of western European corporations, Journal of Financial Economics, 65, 365-395.

[33] Fama, E. F., and K. R. French, 1993, Common Risk factors in the Returns on Bonds and Stocks, Journal of Financial Economics, 53, 3-53.

[34] Financial Reporting Council, 2009, Review of the Effectiveness of the Combined Code. Progress Report and Second Consultation, available at http://www.frc.org.uk/corporate/reviewCombined.cfm

[35] Gompers, P., J. Ishii and A. Metrick, 2003, Corporate governance and equity prices, Quarterly Journal of Economics 118, 107-155.

[36] Goyal, V. K., K. Lehn, and S. Racic, 2002, Growth Opportunities and Corporate Debt Policy: The Case of the U.S. Defense Industry, Journal of Financial Economics, 64, 35-59

[37] Harris, M., and A. Raviv, 2008, A Theory of Board Control and Size, Review of Financial Studies, 21, 1797-1832.

[38] Healy, P.M., and K. G. Palepu, 2001, Information Asymmetry, Corporate Disclosure, and the Capital Markets: A Review of the Empirical Disclosure Literature, Journal of Accounting and Economics, 31, 405-440.

[39] Hermalin, B. E. and M. S. Weisbach, 2003, Boards of Directors as an Endogenously Determined Institution: A Survey of the Economic Literature, Economic Policy Review, 9, 7-26.

[40] Hollander, S., M. Pronk, and E. Roelofsen, 2010, Does Silence Speak? An Empirical Analysis of Disclosure Choices During Conference Calls, Journal of Accounting Research (article in press).

[41] Hope, O-K., and W. B. Thomas, 2008, Managerial Empire Building and Firm Disclosure, Journal of Accounting Research, 46, 591-626.

[42] Hovakimian, A., G. Hovakimian, and H. Tehranian, 2004, Determinants of target capital structure: The case of combined debt and equity financing, Journal of Financial Economics, 71, $517-541$.

[43] Kayhan, A. and S. Titman, 2007, Firms' histories and their capital structure, Journal of Financial Economics, 83, 1-32

[44] Khanna, T., K. Palepu, and S. Srinivasan, 2004, Disclosure Practices of Foreign Companies Interacting with U.S. Markets, Journal of Accounting Research 42, 475-508.

[45] Klapper, L., and I. Love, 2004, Corporate governance, investor protection, and performance in emerging countries, Journal of Corporate Finance, 10, 703-28. 
[46] Kothari, S., S. Shu, and P. Wysocki, 2009, Do managers withhold bad news?, Journal of Accounting Research, 47, 241-276.

[47] Jensen, M.C., 1986, Agency Cost of Free Cash Flow, Corporate Finance, and Takeovers, American Economic Review, 76, 323-329.

[48] John, K., L.P. Litov. and B. Y. Yeung, 2008, Corporate Governance and Risk Taking, Journal of Finance, 63, 1679-1728.

[49] Lang, M., K. Lins, and D. Miller, 2004, Concentrated control, analyst following, and valuation: Do analyst matter most when investors are protected least?, Journal of Accounting Research, $42,589-623$.

[50] Leuz, C., D. Nanda, and P. Wysocki, 2003, Earnings Management and Investor Protection: An International Comparison, Journal of Financial Economics, 69, 505-527.

[51] Leuz, C., and P. Wysocki, 2008, Economic Consequences of Financial Reporting and Disclosure Regulation: A Review and Suggestions for Future Research, unpublished working paper.

[52] Leuz, C., A. Triantis and T. Wang, 2008, Why Do Firms Go Dark? Causes and Economic Consequences of Voluntary SEC Deregistrations, Journal of Accounting and Economics 45 (2008), 181-208.

[53] Linck, J.S., J.M. Netter, and T. Yang, 2008, The determinants of board structure, Journal of Financial Economics, 87, 308-328.

[54] Raheja, G.C., 2005, Determinants of Board Size and Composition: A Theory of Corporate Boards, Journal of Financial and Quantitative Analysis, 40, 283-306.

[55] Shleifer, A., and R.W. Vishny, 1986, Large Shareholders and Corporate Control, Journal of Political Economy, 94, 461-88

[56] Shleifer, A., and R.W. Vishny, 1997, A Survey of Corporate Governance, Journal of Finance, $52,737-84$.

[57] Stock, J.H., J.H. Wright, and M. Yogo, 2002, A survey of weak instruments and weak indentification in generalized method of moments, Journal of Business and Economics Statistics, 20, 518-529.

[58] Titman, S., J. Wei, and F. Xie, 2004, Capital Investments and Stock Returns, Journal of Financial and Quantitative Analysis, 39, 677-700.

[59] Williamson, O., 1964, The Economics of Discretionary Behavior: Managerial Objectives in a Theory of the Firm, Englewood Cliffs, N.J. Prentice Hall Press. 


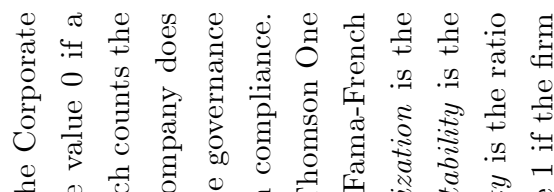

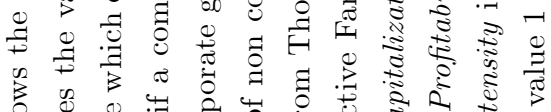

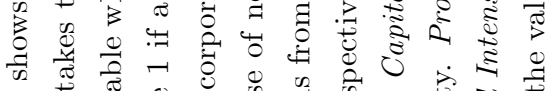

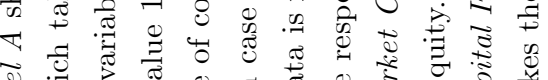

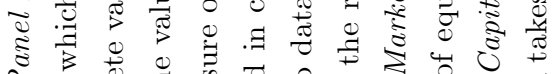

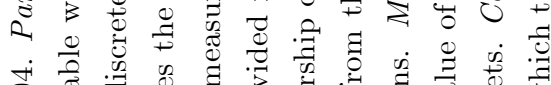
广 D

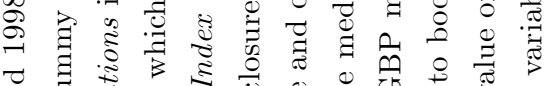
च

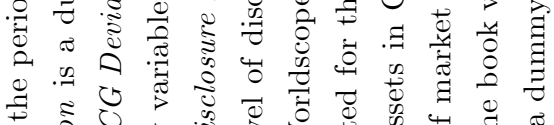

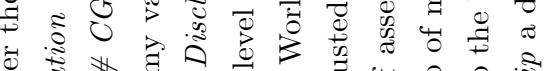

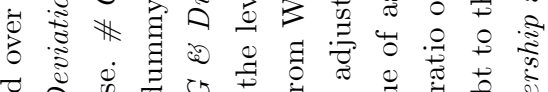

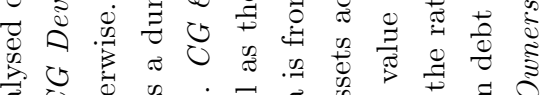

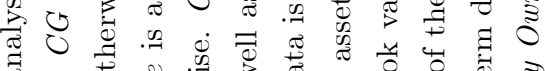
ब ख્व

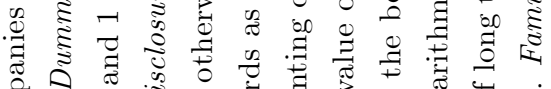
者

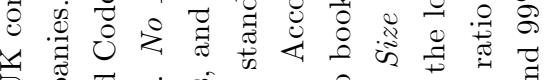

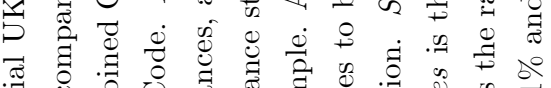

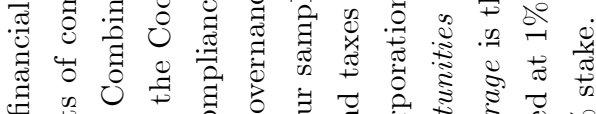

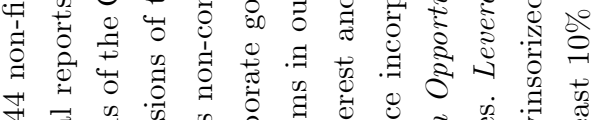

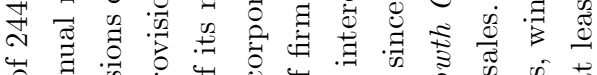

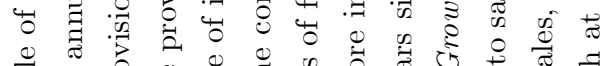

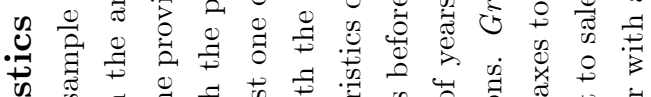

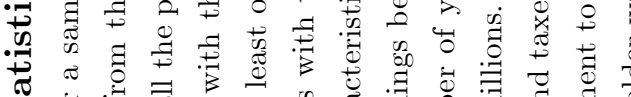
霥

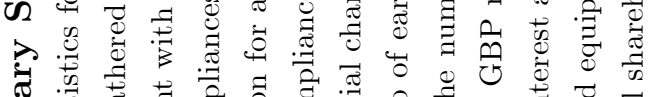

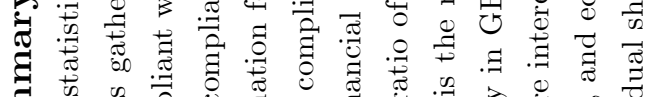

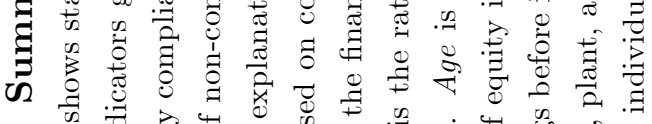

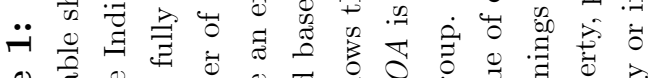

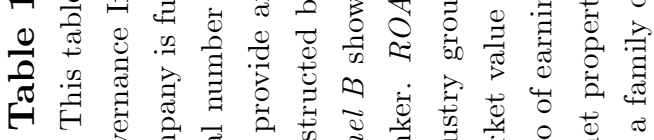

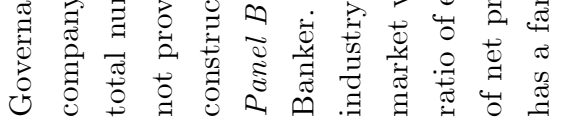

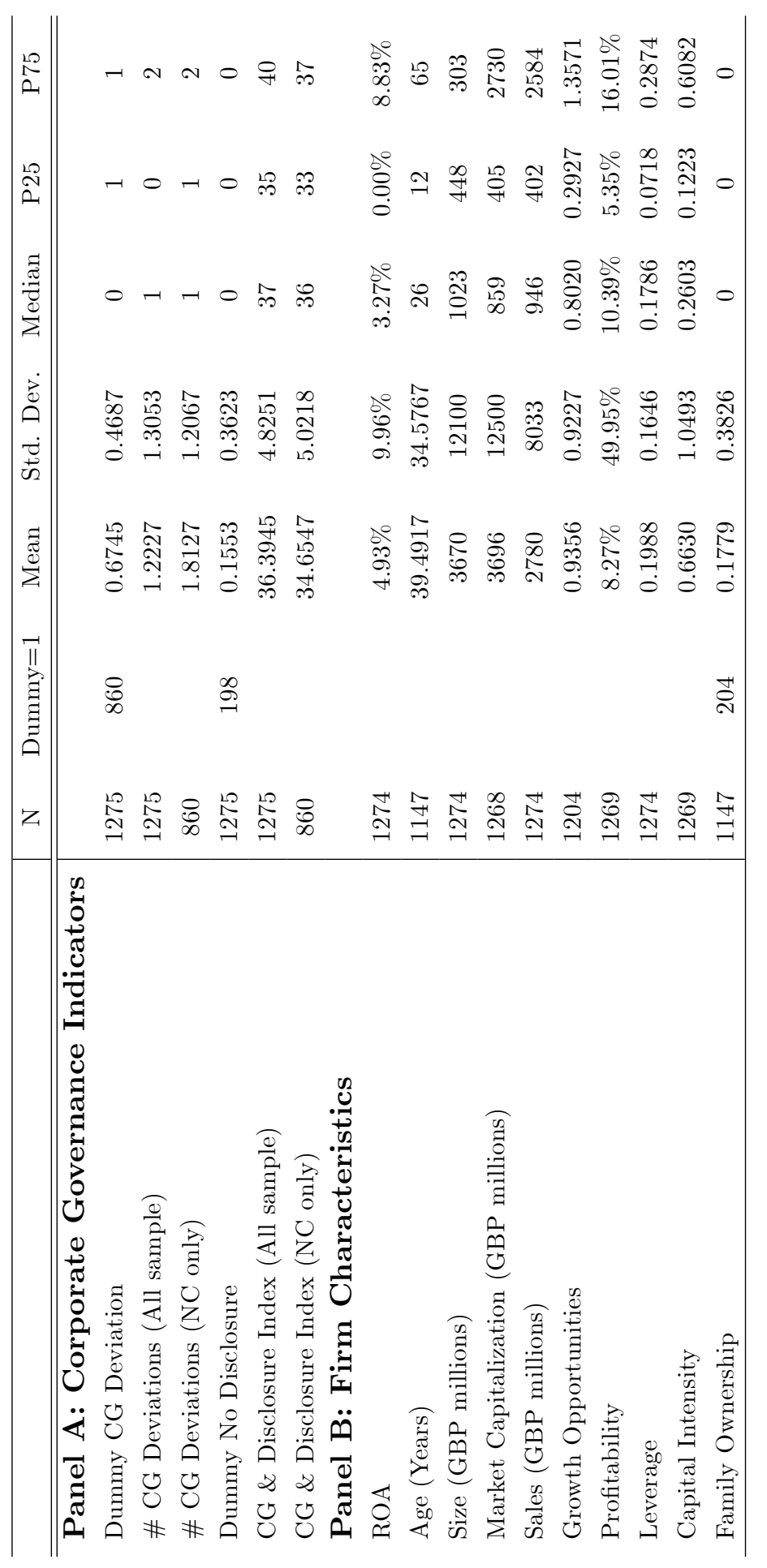




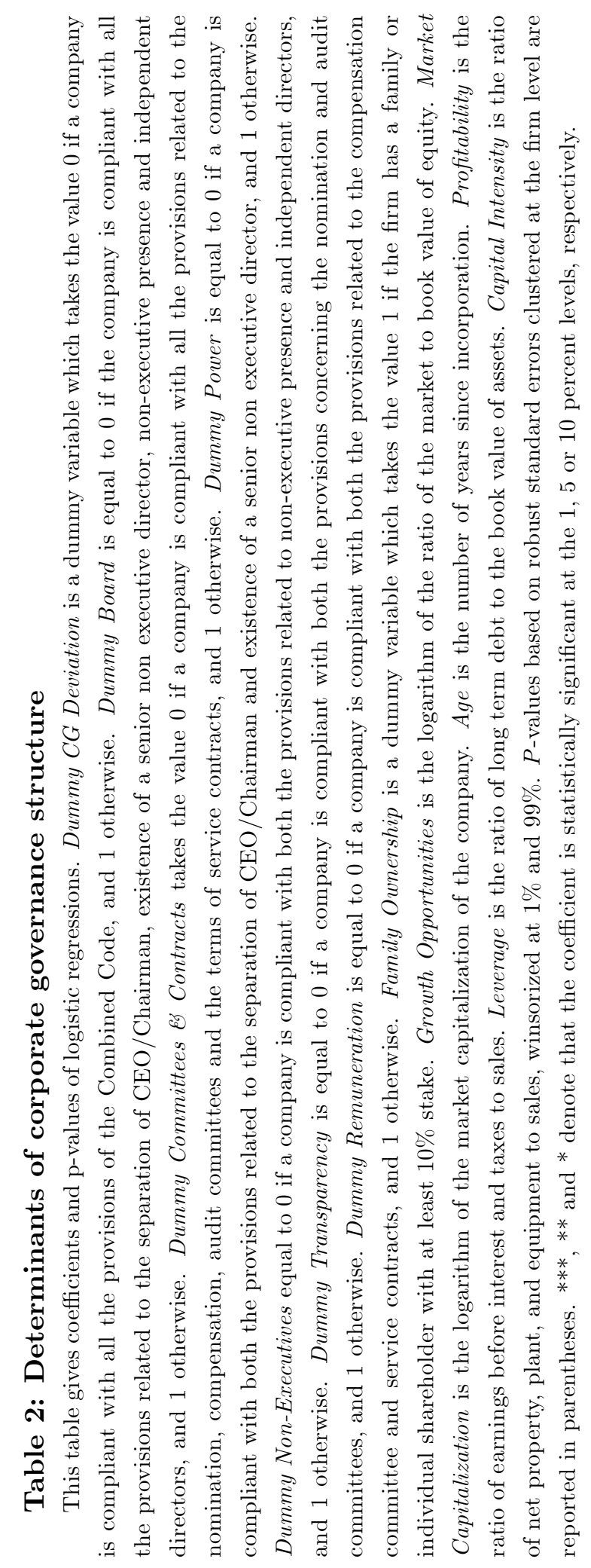




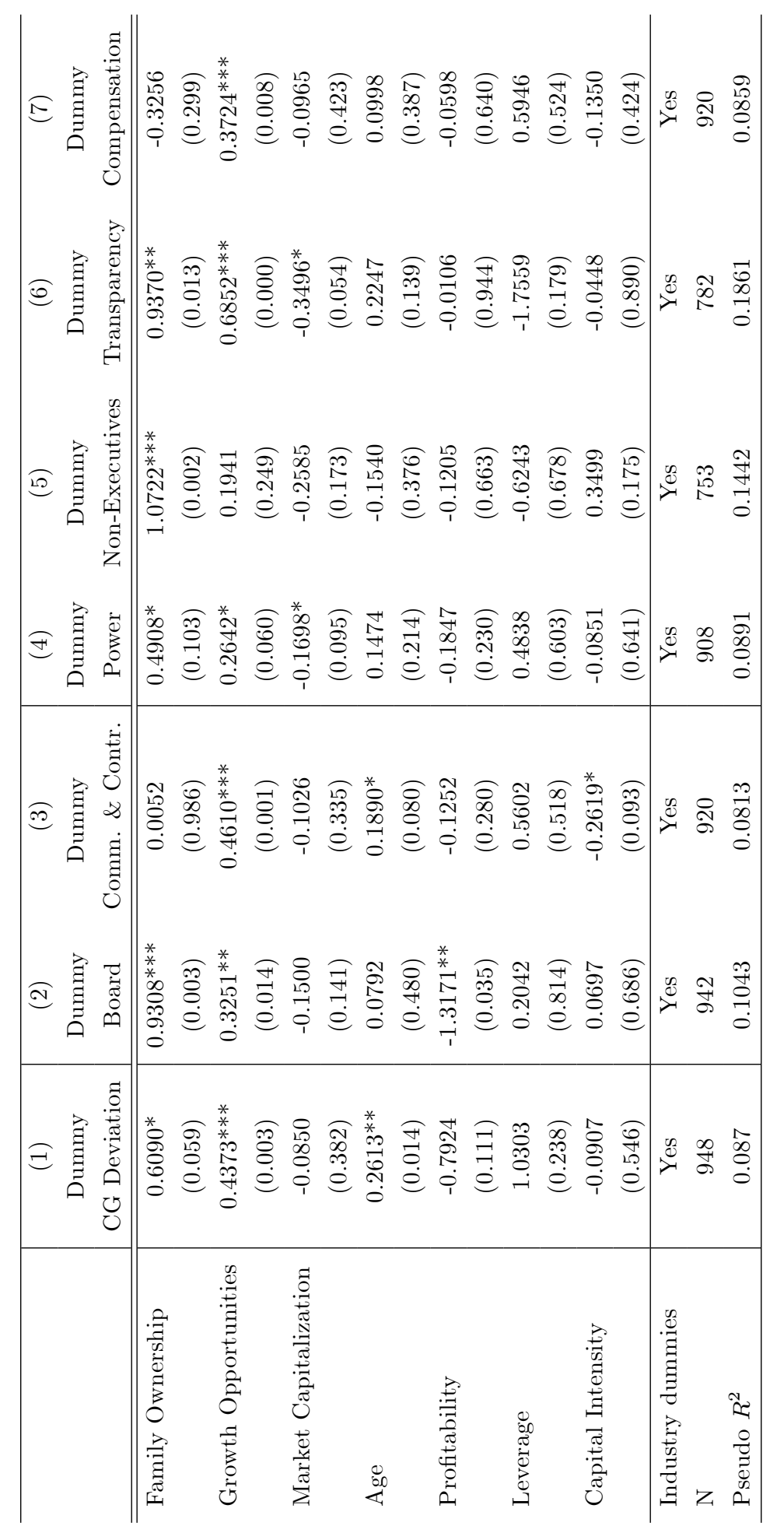


Table 3: Determinants of corporate governance structure and disclosure quality

This table gives coefficients and p-values of a multinomial logistic regression with the following dummy variable groups equal to 1, and 0 otherwise: No Disclosure if a company does not provide any explanation for at least one of its non-compliances; Poor Disclosure if the company has a value of $C G \&$ E Disclosure Index less than the median 37; Some Disclosure if the company has a value of $C G \& \mathcal{E}$ Disclosure Index equal to or greater than the median of 37 , but less than 40; Full Disclosure if the company provides informative explanations (Type 5) for all its non-compliances. The base variable for the regression are companies that are fully compliant with all provisions of the Code. Family Ownership is a dummy variable which takes the value 1 if the firm has a family or individual shareholder with at least $10 \%$ stake, and 0 otherwise. Growth Opportunities is the logarithm of the ratio of the market to book value of equity. Market Capitalization is the logarithm of the market capitalization of the company. Age is the number of years since incorporation. Profitability is the ratio of earnings before interest and taxes to sales. Leverage is the ratio of long term debt to the book value of assets. Capital Intensity is the ratio of net property, plant, and equipment to sales, winsorized at $1 \%$ and $99 \%$. $P$-values based on robust standard errors clustered at the firm level are reported in parentheses. $* * * * *$ and $*$ denote that the coefficient is statistically significant at the 1,5 or 10 percent levels, respectively.

\begin{tabular}{|c|c|c|c|c|}
\hline & (1) & $(2)$ & $(3)$ & $(4)$ \\
\hline & \multicolumn{4}{|c|}{ Multinomial Logit (Base: Compliant Companies) } \\
\hline & No Disclosure & Poor Disclosure & Some Disclosure & Full Disclosure \\
\hline \multirow[t]{2}{*}{ Family Ownership } & $0.7198^{*}$ & $0.6828^{*}$ & 0.4685 & 1.0436 \\
\hline & $(0.068)$ & $(0.079)$ & $(0.236)$ & $(0.174)$ \\
\hline \multirow[t]{2}{*}{ Growth Opportunities } & $0.5253^{* * *}$ & $0.4230^{* *}$ & $0.4196^{* * *}$ & $0.6191^{* *}$ \\
\hline & $(0.006)$ & $(0.021)$ & $(0.008)$ & $(0.039)$ \\
\hline \multirow[t]{2}{*}{ Market Capitalization } & $-0.3261^{*}$ & -0.2110 & 0.0539 & $0.5661^{* * *}$ \\
\hline & $(0.083)$ & $(0.115)$ & $(0.612)$ & $(0.002)$ \\
\hline \multirow[t]{2}{*}{ Age } & $0.4494^{* *}$ & $0.2614^{*}$ & 0.1613 & 0.2700 \\
\hline & $(0.014)$ & $(0.057)$ & $(0.183)$ & $(0.213)$ \\
\hline \multirow[t]{2}{*}{ Profitability } & $-0.8716^{*}$ & -0.7155 & -0.8216 & $-1.0575^{* *}$ \\
\hline & $(0.099)$ & $(0.160)$ & $(0.105)$ & $(0.041)$ \\
\hline \multirow[t]{2}{*}{ Leverage } & 0.7986 & $2.0583^{*}$ & -0.3961 & $4.7938^{* *}$ \\
\hline & $(0.531)$ & $(0.066)$ & $(0.722)$ & $(0.026)$ \\
\hline \multirow[t]{2}{*}{ Capital Intensity } & -0.0702 & -0.1259 & 0.0238 & -0.1159 \\
\hline & $(0.718)$ & $(0.538)$ & $(0.898)$ & $(0.754)$ \\
\hline Industry dummies & Yes & Yes & Yes & Yes \\
\hline $\mathrm{N}$ & 980 & 980 & 980 & 980 \\
\hline Pseudo $\mathrm{R}^{2}$ & \multicolumn{4}{|c|}{0.163} \\
\hline
\end{tabular}


Table 4: Corporate Governance and Operating Performance - Univariate Results

This table reports the results of univariate comparisons of average ROA between various categories across the sample period 1998 to 2004. ROA is defined as the ratio of earnings before interest and taxes to book value of assets adjusted for the median from the respective Fama-French industry group. $C G \mathscr{E}$ Disclosure Index is a measure of corporate governance constructed based on compliances with the corporate governance standards as well as the level of disclosure provided in case of non compliance. $P$-values are reported based on two-sided t-test of difference in means.

Panel A: ROA Compliant vs. Non-Compliant

\begin{tabular}{l|cc}
\hline & ROA & N \\
\hline \hline Compliant & $5.26 \%$ & 415 \\
Non-Compliant & $4.76 \%$ & 859 \\
Total & $4.93 \%$ & 1274 \\
\hline p-value & 0.406 & \\
\hline
\end{tabular}

Panel B: ROA Compliant vs. Non-compliant with One non-compliance

\begin{tabular}{l|cc}
\hline & ROA & $\mathrm{N}$ \\
\hline \hline Compliant & $5.26 \%$ & 415 \\
One non-compliance & $5.35 \%$ & 458 \\
Total & $5.31 \%$ & 873 \\
\hline p-value & 0.891 & \\
\hline
\end{tabular}

Panel C: ROA Compliant vs. Non-compliant with Two non-compliances

\begin{tabular}{l|cl}
\hline & ROA & N \\
\hline \hline Compliant & $5.26 \%$ & 415 \\
Two non-compliances & $3.63 \%$ & 252 \\
Total & $4.64 \%$ & 667 \\
\hline p-value & $0.041^{* *}$ & \\
\hline
\end{tabular}

Panel D: ROA Compliant vs. Non-compliant with Three or more non-compliances

\begin{tabular}{l|ll}
\hline & ROA & N \\
\hline \hline Compliant & $5.26 \%$ & 415 \\
Three or more non-compliances & $4.88 \%$ & 149 \\
Total & $5.16 \%$ & 564 \\
\hline p-value & 0.691 & \\
\hline
\end{tabular}

Panel E: ROA CG \& Disclosure Index greater vs. lower than median

\begin{tabular}{l|lc|ll}
\hline & ROA & N & ROA & N \\
\hline \hline$C G \&$ Disclosure Index > Median & $5.63 \%$ & 619 & $5.84 \%$ & 346 \\
$C G \&$ Disclosure Index <= Median & $4.26 \%$ & 655 & $4.04 \%$ & 513 \\
Total & $4.93 \%$ & 1274 & $4.76 \%$ & 859 \\
\hline p-value & $0.014^{* *}$ & & $0.009^{* * *}$ & \\
Sample & All & & NC & \\
\hline
\end{tabular}




\section{Table 5: Corporate Governance and Operating Performance - Multivariate Regres- sions}

This table gives coefficients and p-values of ordinary least squares regressions with one year ahead industryadjusted $R O A$ as the dependent variable, where $R O A$ is defined as the ratio of earnings before interest and taxes to book value of assets adjusted for the median from the respective Fama-French industry group. No Disclosure is a dummy variable which takes the value 1 if a company does not provide an explanation for at least one of its non-compliances, and 0 otherwise. $C G \&$ Disclosure Index is a measure of corporate governance constructed based on compliances with the corporate governance standards as well as the level of disclosure provided in case of non compliance. \# CG Deviations is a discrete variable which counts the total number of non-compliances with the provisions of the Code. Dummy CG Deviation is a dummy variable that takes the value 0 if a company is fully compliant with all the provisions of the Combined Code, and 1 otherwise. Size is the logarithm of book value of assets. Growth Opportunities is the logarithm of the ratio of the market to book value of equity and excludes negative values. Profitability is the ratio of earnings before interest and taxes to sales. Leverage is the ratio of long term debt to the book value of assets. Capital Intensity is the ratio of net property, plant, and equipment to sales, winsorized at $1 \%$ and $99 \%$. Family Ownership is a dummy variable which takes the value 1 if the firm has a family or individual shareholder with at least $10 \%$ stake, and 0 otherwise. $P$-values based on robust standard errors clustered at the firm level are reported in parentheses. ${ }^{* *},{ }^{* *}$ and ${ }^{*}$ denote that the coefficient is statistically significant at the 1,5 or 10 percent levels, respectively. 


\begin{tabular}{|c|c|c|c|c|c|c|c|}
\hline & $(1)$ & $(2)$ & $(3)$ & $(4)$ & $(5)$ & $(6)$ & $(7)$ \\
\hline No Disclosure & $\begin{array}{c}-0.0142^{*} \\
(0.079)\end{array}$ & $\begin{array}{l}-0.0163^{*} \\
(0.061)\end{array}$ & & & & & \\
\hline CG \& Disclosure Index & & & $\begin{array}{c}0.0014^{* *} \\
(0.046)\end{array}$ & $\begin{array}{c}0.0021^{* * *} \\
(0.006)\end{array}$ & & & \\
\hline \# CG Deviations & & & & & $\begin{array}{l}-0.0024 \\
(0.447)\end{array}$ & & \\
\hline Dummy CG Deviation & & & & & & $\begin{array}{l}0.0025 \\
(0.767)\end{array}$ & $\begin{array}{c}-0.0679^{* *} \\
(0.015)\end{array}$ \\
\hline $\begin{array}{l}\text { (Dummy CG Deviation)* } \\
\text { (CG \& Disclosure Index) }\end{array}$ & & & & & & & $\begin{array}{c}0.0020^{* * *} \\
(0.006)\end{array}$ \\
\hline Size & $\begin{array}{r}-0.0065 \\
(0.116)\end{array}$ & $\begin{array}{r}-0.0066 \\
(0.186)\end{array}$ & $\begin{array}{c}-0.0072^{*} \\
(0.090)\end{array}$ & $\begin{array}{l}-0.0081 \\
(0.104)\end{array}$ & $\begin{array}{l}-0.0065 \\
(0.137)\end{array}$ & $\begin{array}{l}-0.0060 \\
(0.158)\end{array}$ & $\begin{array}{c}-0.0074^{*} \\
(0.077)\end{array}$ \\
\hline Growth Opportunities & $\begin{array}{c}0.0366^{* * *} \\
(0.000)\end{array}$ & $\begin{array}{c}0.0396^{* * *} \\
(0.000)\end{array}$ & $\begin{array}{c}0.0368^{* * *} \\
(0.000)\end{array}$ & $\begin{array}{c}0.0402^{* * *} \\
(0.000)\end{array}$ & $\begin{array}{c}0.0367^{* * *} \\
(0.000)\end{array}$ & $\begin{array}{c}0.0365^{* * *} \\
(0.000)\end{array}$ & $\begin{array}{c}0.0370^{* * *} \\
(0.000)\end{array}$ \\
\hline Profitability & $\begin{array}{c}0.0609^{* * *} \\
(0.000)\end{array}$ & $\begin{array}{c}0.0561^{* * *} \\
(0.000)\end{array}$ & $\begin{array}{c}0.0613^{* * *} \\
(0.000)\end{array}$ & $\begin{array}{c}0.0571^{* * *} \\
(0.000)\end{array}$ & $\begin{array}{c}0.0612^{* * *} \\
(0.000)\end{array}$ & $\begin{array}{c}0.0614^{* * *} \\
(0.000)\end{array}$ & $\begin{array}{c}0.0619^{* * *} \\
(0.000)\end{array}$ \\
\hline Leverage & $\begin{array}{c}-0.1337^{* * *} \\
(0.000)\end{array}$ & $\begin{array}{c}-0.1127^{* * *} \\
\quad(0.005)\end{array}$ & $\begin{array}{c}-0.1323^{* * *} \\
(0.000)\end{array}$ & $\begin{array}{c}-0.1122^{* * *} \\
\quad(0.006)\end{array}$ & $\begin{array}{c}-0.1330^{* * *} \\
(0.000)\end{array}$ & $\begin{array}{c}-0.1339^{* * *} \\
(0.000)\end{array}$ & $\begin{array}{c}-0.1342^{* * *} \\
(0.000)\end{array}$ \\
\hline Capital Intensity & $\begin{array}{c}0.0053^{*} \\
(0.092)\end{array}$ & $\begin{array}{c}0.0072^{*} \\
(0.092)\end{array}$ & $\begin{array}{r}0.0052 \\
(0.105) \\
\end{array}$ & $\begin{array}{c}0.0073^{*} \\
(0.097)\end{array}$ & $\begin{array}{c}0.0053^{*} \\
(0.099)\end{array}$ & $\begin{array}{c}0.0056^{*} \\
(0.091)\end{array}$ & $\begin{array}{c}0.0058^{*} \\
(0.080)\end{array}$ \\
\hline Year dummies & Yes & Yes & Yes & Yes & Yes & Yes & Yes \\
\hline Sample & All & $\mathrm{NC}$ & All & $\mathrm{NC}$ & All & All & All \\
\hline $\mathrm{N}$ & 1192 & 806 & 1192 & 806 & 1192 & 1192 & 1192 \\
\hline Adjusted $R^{2}$ & 0.274 & 0.302 & 0.275 & 0.307 & 0.272 & 0.271 & 0.277 \\
\hline
\end{tabular}


Table 5: Corporate Governance and Operating Performance - Multivariate Regressions (continued)

\begin{tabular}{|c|c|c|c|c|}
\hline & $(8)$ & $(9)$ & $(10)$ & $(11)$ \\
\hline \multirow[t]{2}{*}{ No Disclosure } & -0.0143 & $-0.0181^{*}$ & & \\
\hline & $(0.123)$ & $(0.086)$ & & \\
\hline \multirow[t]{2}{*}{ CG \& Disclosure Index } & & & $0.0016^{*}$ & $0.0028^{* * *}$ \\
\hline & & & $(0.089)$ & $(0.006)$ \\
\hline \multirow[t]{2}{*}{ Family Ownership } & -0.0057 & -0.0080 & 0.0334 & 0.0636 \\
\hline & $(0.641)$ & $(0.582)$ & $(0.437)$ & $(0.186)$ \\
\hline \multirow[t]{2}{*}{ (No Disclosure)*(Family Ownership) } & 0.0158 & 0.0190 & & \\
\hline & $(0.429)$ & $(0.390)$ & & \\
\hline (CG \& Disclosure Index $)^{*}$ & & & -0.0010 & -0.0019 \\
\hline (Family Ownership) & & & $(0.445)$ & $(0.206)$ \\
\hline \multirow[t]{2}{*}{ Size } & -0.0059 & -0.0060 & -0.0065 & -0.0077 \\
\hline & $(0.220)$ & $(0.289)$ & $(0.181)$ & $(0.164)$ \\
\hline \multirow[t]{2}{*}{ Growth Opportunities } & $0.0386^{* * *}$ & $0.0418^{* * *}$ & $0.0389 * * *$ & $0.0428^{* * *}$ \\
\hline & $(0.000)$ & $(0.000)$ & $(0.000)$ & $(0.000)$ \\
\hline \multirow[t]{2}{*}{ Profitability } & $0.0594^{* * *}$ & $0.0556^{* * *}$ & $0.0600^{* * *}$ & $0.0567^{* * *}$ \\
\hline & $(0.000)$ & $(0.000)$ & $(0.000)$ & $(0.000)$ \\
\hline \multirow[t]{2}{*}{ Leverage } & $-0.1285^{* * *}$ & $-0.1133^{* *}$ & $-0.1273^{* * *}$ & $-0.1125^{* *}$ \\
\hline & $(0.002)$ & $(0.012)$ & $(0.002)$ & $(0.012)$ \\
\hline \multirow[t]{2}{*}{ Capital Intensity } & 0.0053 & $0.0075^{*}$ & 0.0052 & $0.0077^{*}$ \\
\hline & $(0.101)$ & $(0.093)$ & $(0.107)$ & $(0.087)$ \\
\hline F-Test - Ownership (p-values) & 0.545 & 0.519 & 0.437 & 0.186 \\
\hline Year dummies & Yes & Yes & Yes & Yes \\
\hline Sample & All & $\mathrm{NC}$ & All & $\mathrm{NC}$ \\
\hline Observations & 1072 & 728 & 1072 & 728 \\
\hline Adjusted $R^{2}$ & 0.283 & 0.312 & 0.284 & 0.319 \\
\hline
\end{tabular}




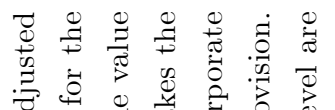

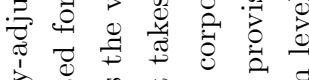

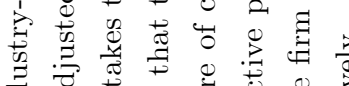

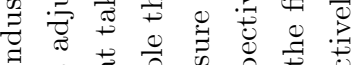

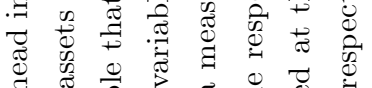

สี

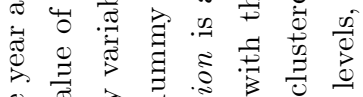

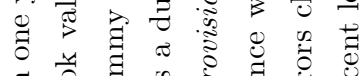

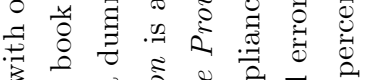

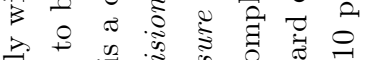

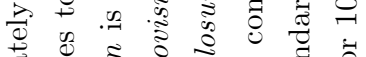

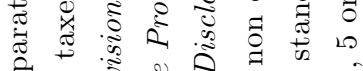

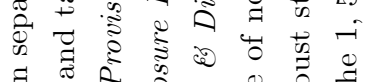

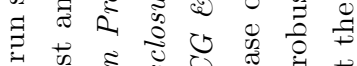

व

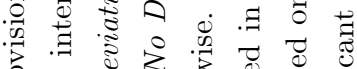

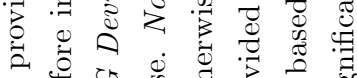

न्ष

D)

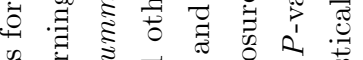

ปี

䨔

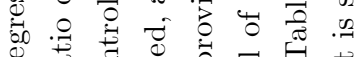

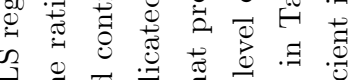

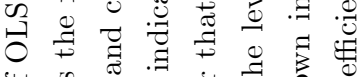

फ

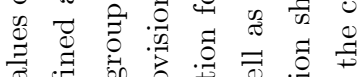

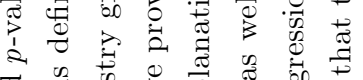

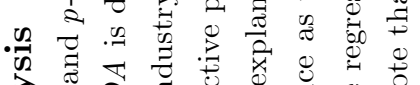

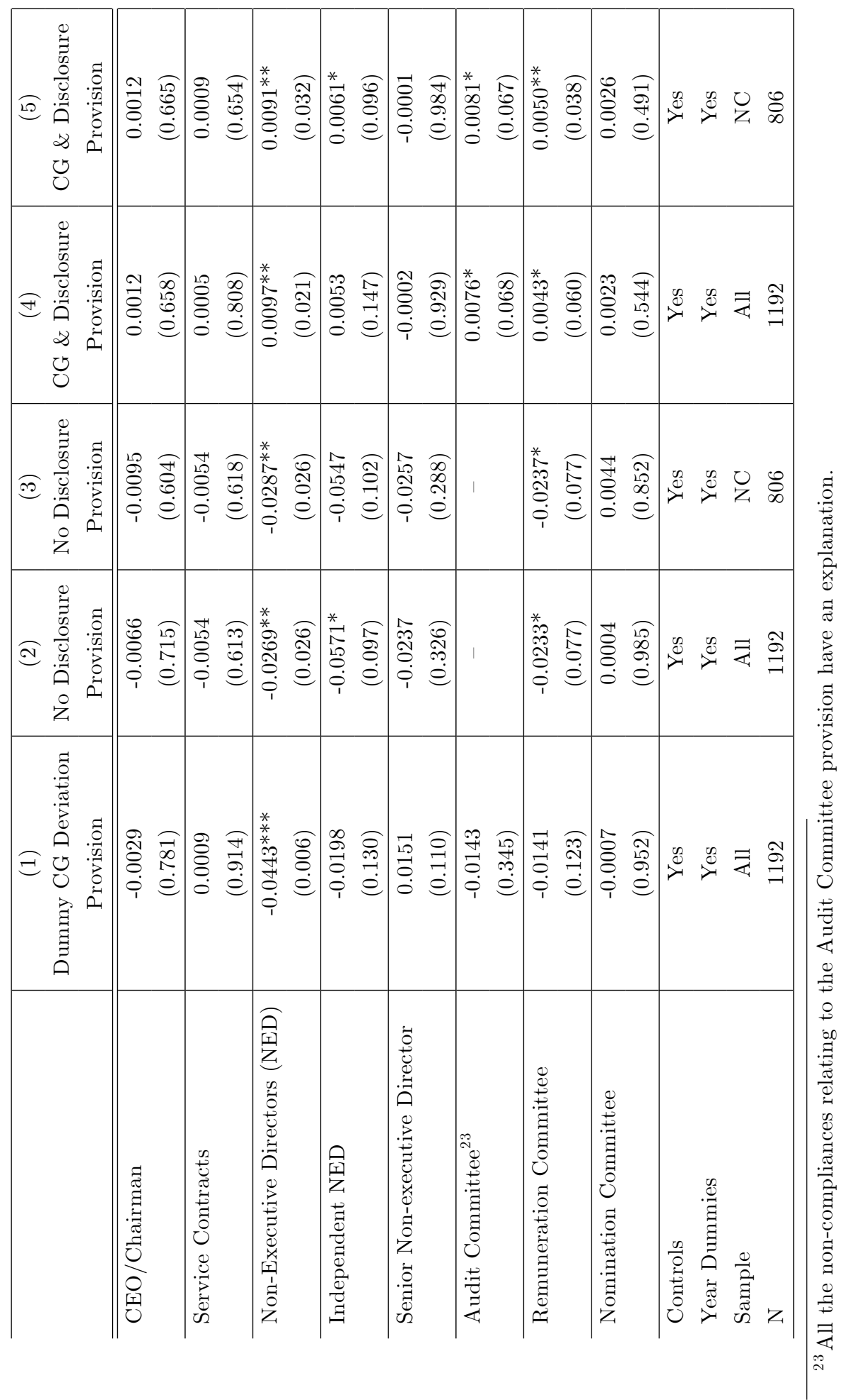


Table 7: Corporate Governance and Operating Performance - Instrumental Variable Regressions

This table reports coefficients and $p$-values of equations estimated using instrumental variable regressions. The dependent variable is one year ahead industry-adjusted $R O A$, where $R O A$ is defined as the ratio of earnings before interest and taxes to book value of assets adjusted for the median from the respective Fama-French industry group. Columns (1) to (4) are estimated using the GMM difference estimators developed by Arellano and Bond (1991) with the lagged dependent variable and treating all other explanatory variables as predetermined. Columns (5) and (6) are estimated by two stage least squares (2SLS) using the average $C G \& \mathcal{E}$ Disclosure Index of firms in the same industry as an instrument; results from the second stage estimations are reported. No Disclosure is a dummy variable that takes the value 1 if a company does not provide an explanation for at least one of its non-compliances, and 0 otherwise. $C G$ \& Disclosure Index is a measure of corporate governance constructed based on compliances with the corporate governance standards as well as the level of disclosure provided in case of non compliance. Size is the logarithm of book value of assets. Growth Opportunities is the logarithm of the ratio of the market to book value of equity. Profitability is the ratio of earnings before interest and taxes to sales. Leverage is the ratio of long term debt to the book value of assets. Capital Intensity is the ratio of net property, plant, and equipment to sales and truncated at $1 \%$ and $99 \%$. Industry adjusted $R O A_{t}$ is the lagged dependent variable. $P$-values are reported in parentheses. ${ }^{* *},{ }^{* *}$ and ${ }^{*}$ denote that the coefficient is statistically significant at the 1,5 or 10 percent levels, respectively.

\begin{tabular}{|c|c|c|c|c|c|c|}
\hline & \multicolumn{2}{|c|}{ Arellano-Bond Estimators } & \multicolumn{2}{|c|}{ Arellano-Bond Estimators } & \multicolumn{2}{|c|}{ 2SLS Regression ( $2^{\text {nd }}$ Stage $)$} \\
\hline & $(1)$ & $(2)$ & (3) & $(4)$ & $(5)$ & $(6)$ \\
\hline No Disclosure & $\begin{array}{c}-0.0237^{* * *} \\
(0.000)\end{array}$ & $\begin{array}{c}-0.0154^{* * *} \\
(0.000)\end{array}$ & & & & \\
\hline CG \& Disclosure Index & & & $\begin{array}{c}0.0047^{* * *} \\
(0.000)\end{array}$ & $\begin{array}{c}0.0026^{* * *} \\
(0.000)\end{array}$ & $\begin{array}{c}0.0090^{* *} \\
(0.029)\end{array}$ & $\begin{array}{c}0.0063^{* * *} \\
(0.010)\end{array}$ \\
\hline Size & $\begin{array}{c}-0.0258^{* * *} \\
(0.000)\end{array}$ & $\begin{array}{c}-0.0215^{* * *} \\
(0.001)\end{array}$ & $\begin{array}{c}-0.0301^{* * *} \\
(0.000)\end{array}$ & $\begin{array}{c}-0.0225^{* * *} \\
(0.003)\end{array}$ & $\begin{array}{c}-0.0121^{* * *} \\
(0.003)\end{array}$ & $\begin{array}{c}-0.0109^{* *} \\
(0.015)\end{array}$ \\
\hline Growth Opportunities & $\begin{array}{l}0.0013 \\
(0.696)\end{array}$ & $\begin{array}{c}0.0222^{* * *} \\
(0.000)\end{array}$ & $\begin{array}{l}0.0013 \\
(0.702)\end{array}$ & $\begin{array}{c}0.0209^{* * *} \\
(0.000)\end{array}$ & $\begin{array}{c}0.0385^{* * *} \\
(0.000)\end{array}$ & $\begin{array}{c}0.0421^{* * *} \\
(0.000)\end{array}$ \\
\hline Profitability & $\begin{array}{c}0.0400^{* * *} \\
(0.000)\end{array}$ & $\begin{array}{l}-0.0031 \\
(0.639)\end{array}$ & $\begin{array}{c}0.0452^{* * *} \\
(0.000)\end{array}$ & $\begin{array}{l}-0.0008 \\
(0.928)\end{array}$ & $\begin{array}{c}0.0612^{* * *} \\
(0.000)\end{array}$ & $\begin{array}{c}0.0586^{* * *} \\
(0.000)\end{array}$ \\
\hline Leverage & $\begin{array}{c}0.1134^{* * *} \\
(0.000)\end{array}$ & $\begin{array}{c}0.3225^{* * *} \\
(0.000)\end{array}$ & $\begin{array}{c}0.0992^{* * *} \\
(0.000)\end{array}$ & $\begin{array}{c}0.0313^{* * *} \\
(0.000)\end{array}$ & $\begin{array}{c}-0.1447^{* * *} \\
(0.000)\end{array}$ & $\begin{array}{c}-0.1429^{* * *} \\
(0.000)\end{array}$ \\
\hline Capital Intensity & $\begin{array}{c}0.0306^{* * *} \\
(0.000)\end{array}$ & $\begin{array}{c}-0.0126^{* *} \\
(0.038)\end{array}$ & $\begin{array}{c}0.0323^{* * *} \\
(0.000)\end{array}$ & $\begin{array}{c}-0.0132^{* *} \\
(0.022)\end{array}$ & $\begin{array}{l}0.0041 \\
(0.268)\end{array}$ & $\begin{array}{l}0.0083^{*} \\
(0.084)\end{array}$ \\
\hline Industry adjusted $R O A_{t}$ & $\begin{array}{c}0.2998^{* * *} \\
(0.000) \\
\end{array}$ & $\begin{array}{c}0.2996^{* * *} \\
(0.000) \\
\end{array}$ & $\begin{array}{c}0.2461^{* * *} \\
(0.000)\end{array}$ & $\begin{array}{c}0.2629^{* * *} \\
(0.000)\end{array}$ & & \\
\hline Year dummies & Yes & Yes & Yes & Yes & Yes & Yes \\
\hline Sample & All & $\mathrm{NC}$ & All & $\mathrm{NC}$ & All & $\mathrm{NC}$ \\
\hline $\mathrm{N}$ & 695 & 419 & 695 & 419 & 1137 & 769 \\
\hline Kleibergen-Paap Wald F statistic & & & & & 14.46 & 16.31 \\
\hline$p$ value of $A R(1)$ test & 0.00 & 0.00 & 0.00 & 0.00 & & \\
\hline$p$ value of $A R(2)$ test & 0.06 & 0.42 & 0.06 & 0.51 & & \\
\hline
\end{tabular}




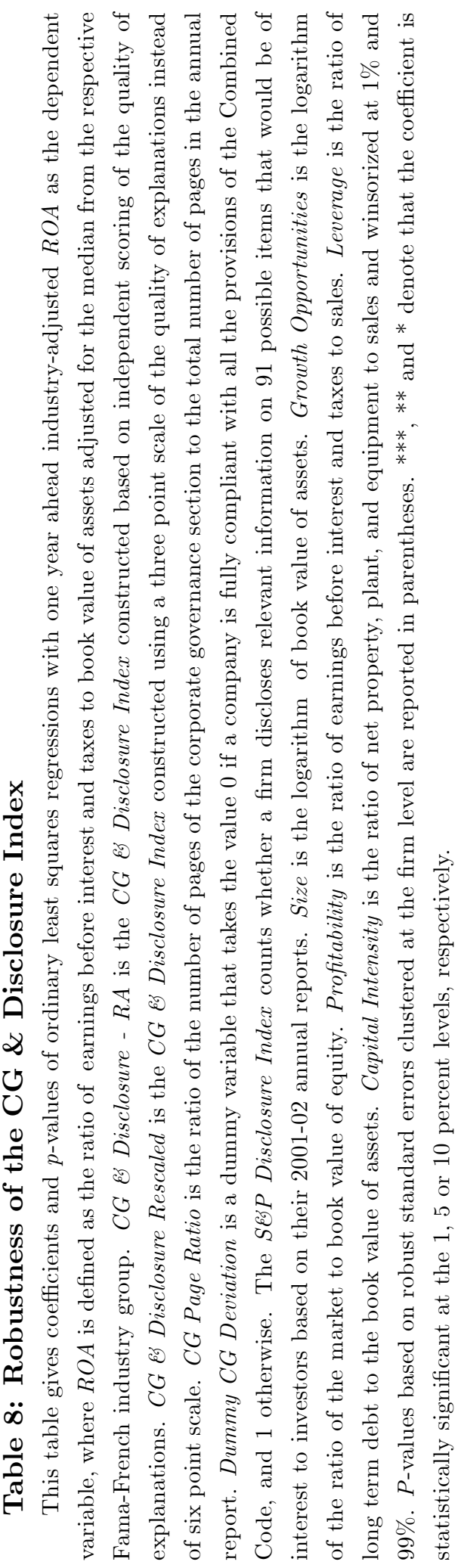




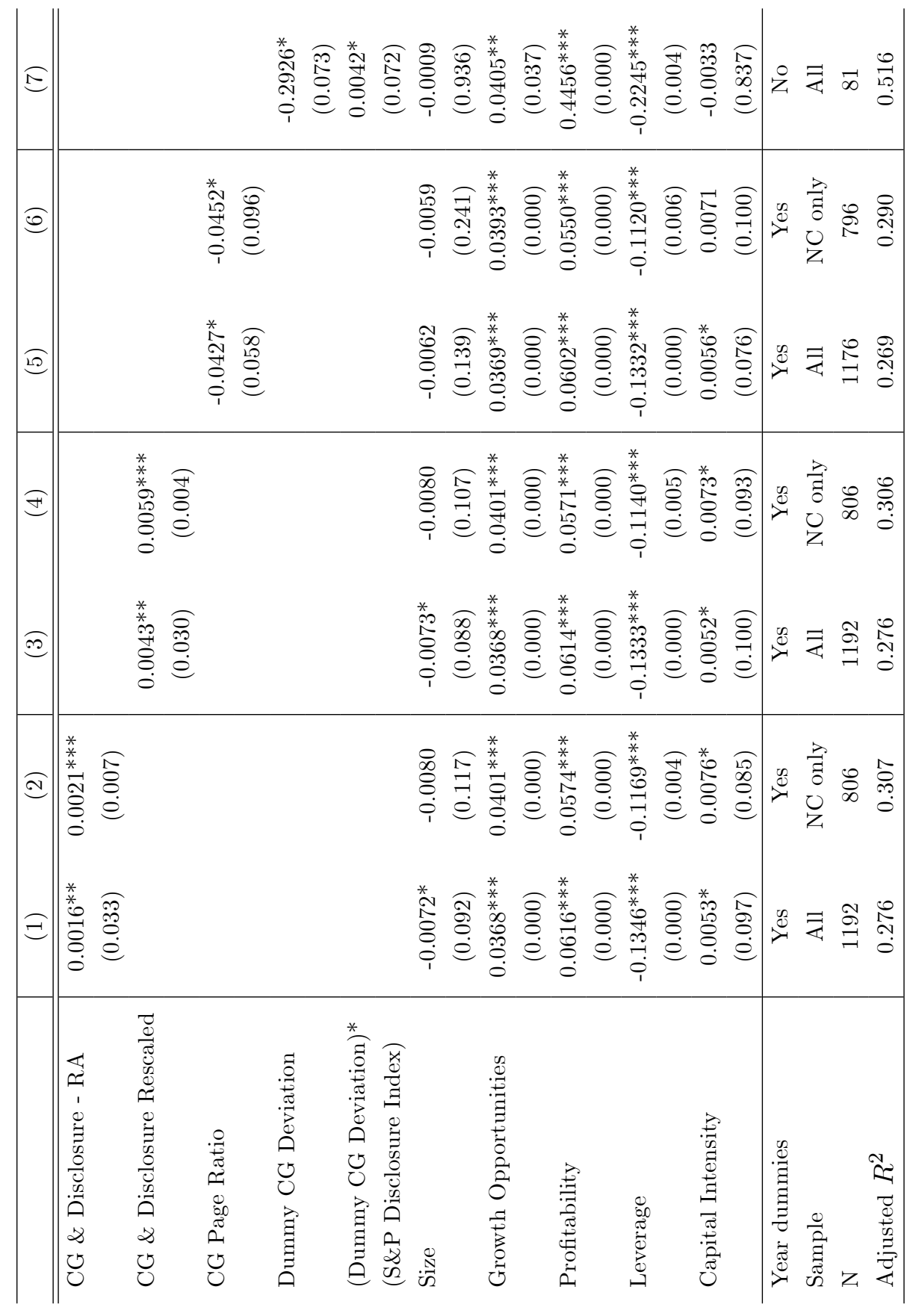




\section{Table 9: Corporate Governance and Stock Market Performance}

This table shows coefficient estimates and p-values from the Fama-French three factor regressions of valueweighted monthly returns of portfolios of firms. The portfolios are formed based on companies either fully compliant with all provisions or with high $C G \& 6$ Disclosure Index defined as being greater than the median (37). The portfolio returns are value-weighted returns which are the result of taking a long position in compliant companies (or high $C G \mathscr{E}$ Disclosure Index companies) and a short position in non-compliant companies (or low CG $\mathscr{E}$ Disclosure Index companies), as shown in Panel A (Panel B). The explanatory variables are $R M R F, S M B$ and $H M L$. These variables are zero-investment portfolios designed to capture market, size, and book-to-market effects, respectively. $P$-values are reported in parentheses. ${ }^{* * *},{ }^{*} *$ and ${ }^{*}$ denote that the coefficient is statistically significant at the 1,5 or 10 percent levels, respectively.

\begin{tabular}{c|c|c|c|c}
\hline & $\alpha$ & RMRF & SMB & HML \\
\hline \hline Panel $A$ & & & & \\
Full compliance v/s & -0.0021 & -0.1029 & -0.0806 & $-0.5713^{* * *}$ \\
Non-compliance & $(0.615)$ & $(0.275)$ & $(0.435)$ & $(0.001)$ \\
\hline Panel $B$ & & & & \\
$C G$ \& Disclosure Index $(>37) \mathrm{v} / \mathrm{s}$ & $0.0106^{*}$ & 0.0355 & $0.3861^{* *}$ & $-0.4064^{* * *}$ \\
$C G$ \& Disclosure Index $(\leq 37)$ & $(0.073)$ & $(0.790)$ & $(0.010)$ & $(0.005)$ \\
\hline
\end{tabular}




\section{Table 10: Corporate Governance and Agency Costs}

This table gives coefficients and $p$-values of a median regression with Capex/Sales as the dependent variable, where Capex is the ratio of capital expenditure to sales adjusted for the median from the respective Fama-French industry group. No Disclosure is a dummy variable which takes the value 1 if a company does not provide an explanation for at least one of its non-compliances, and 0 otherwise. CG E Disclosure Index is a measure of corporate governance constructed based on compliances with the corporate governance standards as well as the level of disclosure provided in case of non compliance. Dummy CG Deviation is a dummy variable which takes the value 0 if a company is fully compliant with all the provisions of the Combined Code, and 1 otherwise. \# CG Deviations is a discrete variable that counts the total number of non-compliances with the provisions of the Code. Size is the logarithm of book value of assets. Growth Opportunities is the logarithm of the ratio of the market to book value of equity and excludes negative values. Profitability is the ratio of earnings before interest and taxes to sales. Leverage is the ratio of long term debt to the book value of assets. $P$-values are reported in parentheses. ${ }^{* * *},{ }^{* *}$ and ${ }^{*}$ denote that the coefficient is statistically significant at the 1,5 or 10 percent levels, respectively.

\begin{tabular}{|c|c|c|c|c|c|c|}
\hline & $(1)$ & $(2)$ & $(3)$ & $(4)$ & $(5)$ & (6) \\
\hline No Disclosure & $\begin{array}{c}0.7172^{* *} \\
(0.016)\end{array}$ & $\begin{array}{c}0.8776^{* * *} \\
(0.006)\end{array}$ & & & & \\
\hline CG \& Disclosure Index & & & $\begin{array}{c}-0.0422^{*} \\
(0.083)\end{array}$ & $\begin{array}{c}-0.0547^{*} \\
(0.072)\end{array}$ & & \\
\hline Dummy CG Deviation & & & & & $\begin{array}{l}-0.3585 \\
(0.181)\end{array}$ & \\
\hline \# CG Deviations & & & & & & $\begin{array}{l}0.0801 \\
(0.450)\end{array}$ \\
\hline Size & $\begin{array}{c}-0.2303^{* * *} \\
(0.004)\end{array}$ & $\begin{array}{c}-0.2071^{* *} \\
(0.039)\end{array}$ & $\begin{array}{c}-0.1910^{* *} \\
(0.019)\end{array}$ & $\begin{array}{r}-0.0866 \\
(0.436)\end{array}$ & $\begin{array}{c}-0.1787^{* *} \\
(0.048)\end{array}$ & $\begin{array}{c}-0.1932^{* *} \\
(0.043)\end{array}$ \\
\hline Growth Opportunities & $\begin{array}{c}-0.2371^{* *} \\
(0.048)\end{array}$ & $\begin{array}{l}0.0187 \\
(0.898)\end{array}$ & $\begin{array}{c}-0.2100^{*} \\
(0.072)\end{array}$ & $\begin{array}{l}0.0431 \\
(0.781)\end{array}$ & $\begin{array}{r}-0.1774 \\
(0.187)\end{array}$ & $\begin{array}{r}-0.1850 \\
(0.179)\end{array}$ \\
\hline Profitability & $\begin{array}{c}-12.4223^{* * *} \\
(0.000)\end{array}$ & $\begin{array}{c}-16.4204^{* * *} \\
(0.000)\end{array}$ & $\begin{array}{c}-11.9401^{* * *} \\
(0.000)\end{array}$ & $\begin{array}{c}-15.5242^{* * *} \\
(0.000)\end{array}$ & $\begin{array}{c}-12.5406^{* * *} \\
(0.000)\end{array}$ & $\begin{array}{c}-12.3757^{* * *} \\
(0.000)\end{array}$ \\
\hline Leverage & $\begin{array}{c}4.7723^{* * *} \\
(0.000)\end{array}$ & $\begin{array}{c}3.9543^{* * *} \\
(0.000)\end{array}$ & $\begin{array}{c}4.4672^{* * *} \\
(0.000)\end{array}$ & $\begin{array}{c}3.7816^{* * *} \\
(0.000)\end{array}$ & $\begin{array}{c}4.5316^{* * *} \\
(0.000)\end{array}$ & $\begin{array}{c}4.4733^{* * *} \\
(0.000)\end{array}$ \\
\hline Year Dummies & Yes & Yes & Yes & Yes & Yes & Yes \\
\hline Sample & All & $\mathrm{N}$ & All & $\mathrm{N}$ & All & All \\
\hline Observations & 1196 & 808 & 1196 & 808 & 1196 & 1196 \\
\hline
\end{tabular}




\section{Chart 1: Trends in Compliance and Quality of Explanations}

This graph plots trends in the percentage of companies fully compliant with all the provisions of the Combined Code over the period 1999 - 2004 (dashed line), and the average CG \& Disclosure Index (dotted line) per year.

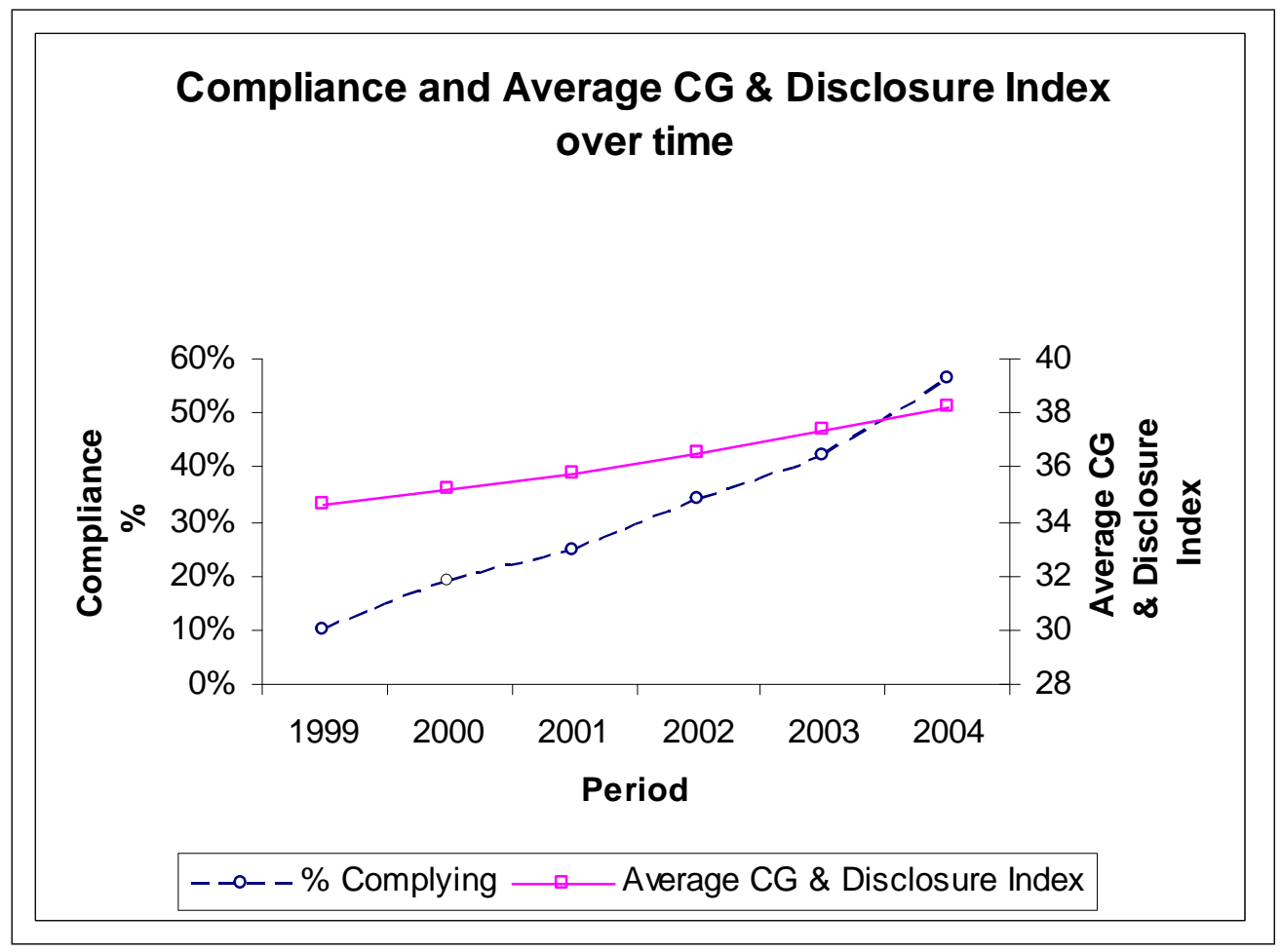

